\title{
Expression of an EF-1 $\alpha$ like rat cDNA, S1, in Escherichia coli and production of a rabbit polyclonal antiserum to the recombinant protein
}

by

\author{
Catherine Heung Luen Liu \\ Department of Anatomy \\ McGill University \\ Montrćal \\ June 1992
}

\begin{abstract}
A Thesis
submitted to the Faculty of Graduate Studies and Research in partial fulfillment of the requirements of the degree of Master of Science
\end{abstract}

${ }^{0}$ Catherine H. L. Liu, 1992 
Name: $\quad$ Catherine Liu

Student Number: 8900367

Department : Anatomy

Thesis Title: $\quad$ Expression of $S 1$ in E. coli and production of an antiserum to $\mathrm{rpS} 1$ (66 characters) 


\section{TABLE OF CONTENTS}

$\boldsymbol{\Lambda b s t r a c t} \quad \ldots \ldots \ldots \ldots \ldots \ldots \ldots \ldots \ldots$

Acknowledgments $\ldots \ldots \ldots \ldots \ldots \ldots \ldots \ldots \ldots$

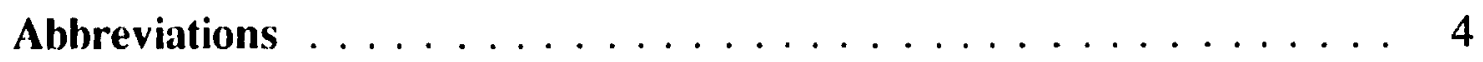

\section{CIIAPTER 1}

IITERATURE REVIEW $\ldots \ldots \ldots \ldots \ldots \ldots \ldots$

a. Molecular basis of cell growth - protein synthesis . . . . . 5

a.1. Transcription and transcriptional control of protein synthesis $\ldots \ldots \ldots \ldots \ldots \ldots \ldots$

a.2. Translation and translational control of protein

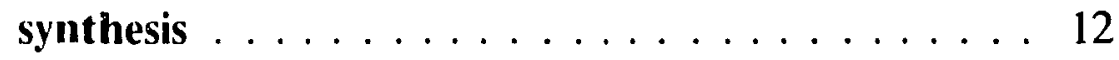

Initiation of translation $\ldots \ldots \ldots \ldots \ldots \ldots \ldots$

Elongation of peptides $\ldots \ldots \ldots \ldots \ldots \ldots$

Termination of translation $\ldots \ldots \ldots \ldots \ldots$

Regulation of translation $\ldots \ldots \ldots \ldots \ldots$

b. The Cell Cycle . . . . . . . . . . . . . . . . . . 19

b.1. Genetic and molecular control of mitosis $\ldots \ldots .21$ 
b.2. Genetic and molecular control of S-phase (DN $\Lambda$ synthesis) $\ldots \ldots \ldots \ldots \ldots \ldots \ldots \ldots$

b.3. Cell cycle arrest during early $G_{1}$ (quiescence) $\ldots .26$

b.4. Cell cycle arrest at late $G_{1}$ (senescence) $\ldots \ldots \ldots$. . 29

b.5. Statin $\ldots \ldots \ldots \ldots \ldots \ldots \ldots \ldots \ldots$

General objectives $\ldots \ldots \ldots \ldots \ldots \ldots \ldots \ldots$

Specific objectives $\ldots \ldots \ldots \ldots \ldots \ldots \ldots$

Diagrams $\ldots \ldots \ldots \ldots \ldots \ldots \ldots \ldots \ldots \ldots \ldots$

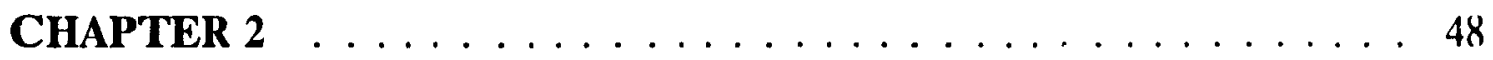

Introduction $\ldots \ldots \ldots \ldots \ldots \ldots \ldots \ldots \ldots$

Materials and Methods $\ldots \ldots \ldots \ldots \ldots \ldots \ldots$

Results $\ldots \ldots \ldots \ldots \ldots \ldots \ldots \ldots \ldots \ldots$

Discussion . . . . . . . . . . . . . . . 59

Figures $\ldots \ldots \ldots \ldots \ldots \ldots \ldots \ldots \ldots \ldots$

\section{CHAPTER 3}

GENEPAL DISCUSSION $\ldots \ldots \ldots \ldots \ldots \ldots$

REFERENCES . . . . . . . . . . . . . . . . . 89 


\section{Abstract}

A previously identified rat cDNA (SI) that shares $78 \%$ nucleotide homology and a predicted $92 \%$ amino acid sequence homology with human EF- $1 \alpha$ was used to express $\mathrm{S} 1$ in $E$. coli and to generate a polyclonal antibody to $\mathrm{pSI}$. A recombinant plasmid pGEX-2T-Sl was constructed, containing the glutathione S-transferase gene. The expressed fusion protein was purified and digested with thrombin to produce a recombinant SI protein ( $\mathrm{rpSl}$ ) containing a slightly modified $\mathrm{N}$-terminus. Purified $\mathrm{rpSl}$ was used to raise a rabbit antiserum which recognized $\mathrm{rpS} 1$ on immunoblots. A polyclonal antiserum to EF-1 $\alpha$ failed to react with $\mathrm{rpSl}$. Similarly the anti-rpS1 does not recognize EF-1 $\alpha$ on immunoblots. Anti-rpS1 therefore is able to distinguish $\mathrm{pS} 1$ from EF-l $\alpha$ despite their extensive amino acid sequence homology. Anti-rpS1 and anti-EF-1 $\alpha$ will be used to study the similarities and differences between $\mathrm{pS} 1$ and EF-1 $\alpha$ in vivo and in vitro. 


\section{Résumé}

Un ADN complémemtaire nommé SI a été prpréalablement isolé à partir d'une banque d'ADN complémentaire chez le rat. SI posséde une forte similarité de sequence avec le facteur d'elongation 1 alpha de l'humanin. SI a étć souscloné dans le vecteur pGEX-2T qui contient le géne recombinant pGEX-2T-S1. Le plasmide recombinant pGEX-2T a été introduit dans la bactérie 101 afin de produire la protéine de fusion $S 1$-glutathione $S$-transférase. La protéine de fusion a alors été clivée avec la thrombine pour produire la protéine rpSI dont la region $\mathrm{N}$-terminale a été injectée dans un lapin pour produire l'anticorps polyclonal antirpS1. Cette anticorps reconnait spécifiquement rpSI mais est incapable de reconnaître le facteur d'élongation 1 alpha. Puisque l'anticorps anti-rpSI est capable de reconnaitre spécifiquemwnt rpSl, cet anticorps sera utilisé alin de distinguer S1 du facteur d'élongation 1 alpha lors de futures expériences. 


\section{Acknowledgments}

I would like to dedicate this thesis to my brothers Pak-loo, James, Philip, Andrew and to my sisters, Susanna and Amy for their countless support during the period of my studies. I thank Dr. Eugenia Wang for giving me the opportunity to undertake this research project, and making available the laboratory facilities. The plasmid pGEX-2T used in this study is a generous gift from Dr. David Ann. I would also like to thank Mr. Michael Marcos for excellent photography. I like to thank the present and past members of Dr. Wang's lab, Lucy, Sha. Guang, Larry, Peter, George, Xin-ying, Lise and Stephen for providing a cheerful working environment. I am grateful to Dr. Lorraine Chalifour and Dr. Anne-Michèle Francoeur for their helpful advice. Special thanks are extended to Dr. Martin Sandig and Menq-Jer Lee for their technical help and for many helpful discussions. Martin also gave me invaluable editorial advice for which I am very grateful.

There are others, too numerous to thank individually, which helped me, one way or another, in bringing this work to completion. 


\section{Abbreviations}

ATP, Adenosine triphosphate

bp, base pair

EDTA, ethylenediaminetetraacetic acid

GST, glutathione S-transferase

HAP, heme activator protein

HDF, human diploid fibroblasts

HRP, horseradish peroxidase

IPR, isoproterenol

IPTG, isopropyl-B-D-thiogalactopyronoside

$\mathrm{kDa}$, kiloDaltons

MPF, maturation promoting factor

PBS, phosphate buffered saline

PCNA, proliferating cell nuclear antigen

PMSF, phenylmethylsulfonyl fluoride

PVDF, polyvinylidene fluoride

SDS-PAGE, sodium dodecyl sulfate - polyacrylamide gel electrophoresis

SRF, serum response factor

TBS, Tris buffered saline

TK, thymidine kinase

UAS, upstream activation sites 


\section{CHAPTER 1}

\section{LITERATURE RIVIEW}

Unicellular and, even more so, multicellular organisms have developed complex mechanisms to maintain their biological function and to reproduce themselves in order to ensure a continuous passage of their genetic information from generation to generation. This is achieved through the evolution of a genetic code and a machinery to read genetic information called transcription and translation; and through evolution of a basic mechanism of mitotic cell division that passes the genetic information on to newly formed cells.

\section{a. Molecular basis of cell growth - protein synthesis}

Cells have the ability to maintain themselves in a high degree of order as a result of their genetic information. This information is encoded by nucleotide sequences of DNA molecules which can be replicated, repaired and expressed by basic genetic processes such as RNA and protein synthesis. The templates for protein synthesis are RNA molecules. Messenger RNA (mRNA) molecules are the information-carrying intermediates for the synthesis of proteins, while ribosomal RNA (rRNA) and transfer RNA (tRNA) form part of the protein synthesizing machinery. All forms of cellular RNA are synthesized from DNA templates by RNA polymerases during the process of transcription. Translation, 
in contrast, is the process of protein synthesis according to the instructions given by the mRNA templates.

\section{a.1. Transcription and transcriptional control of protein synthesis}

Eukaryotic cells contain three distinct classes of RNA polymerases. designated as forms I, II, and III, that transcrib' different sets of genes. RNA polymerase I resides in the nucleolus and synthesizes ribosomal RNA precursors. Both RNA polymerases II and III are present in the nucleoplasm. Whereas RNA polymerase III synthesizes tRNAs and many of the small nuclear RNAs, RNA polymerase II, not only transcribes protein-encoding genes, but also forms the most important part of the regulatory control at the level of messenger RNA transcription (Chambon, 1975). Recently DNA elements, promoters, enhancers and silencers were identified to regulate initiation of transcription through specific DNA-binding proteins (Maniatis et al., 1987).

In the early 80 's, in vitro transcription systems were developed, and general transcription factors were isolated which are involved in the complex process of transcription initiation (Henitz and Roeder, 1982). These developments stimulated a renewed interest in all forms of RNA polymerases and how they interact with the DNA during transcription.

RNA polymerase II is a multisubunit enzyme with a molecular mass of 50 $\mathrm{kDa}$, composed of two large polypeptides and a collection of smaller ones. The 
small polypeptides, less than 10 in number, have sizes ranging from 10 to 40 kDa. The largest subunit of RNA polymerase II has been isolated and shown to exist in multiple subforms (Sentenac, 1985), resulting in RNA polymerase II heterogeneity. These subforms, according to Kedinger et al. (1974), are called IIO, IIa and IIb. RNA polymerase Ila is the unmodified product of the largest subunit gene with a molecular mass of $240 \mathrm{kDa}$ which is highly susceptible to proteolysis. In vitro phosphorylation of calf thymus enzyme (mainly Ila and IIb) by casein kinase I showed that most phosphate groups are incorporated into the C-terminal part of the polypeptide (Dahmus, 1981). This carboxyl terminal domain is rich in proline, serine, threonine and tyrosine (Corden et al., 1985) and therefore contains multiple phosphorylation sites. II0 is a phosphorylated form of IIa, and Ilb is an unphosphorylated cleavage product of IIa generated by proteolysis that lacks the carboxyl terminal domain, with a reduced size of 180 kDa. The phosphorylated RNA polymerase II0 was found in yeast, plant and animal cells (Dahimus, 1981; Sentenac, 1985). Phosphatase treatment of the (IIa) $240 \mathrm{kDa}$ form of calf thymus RNA polymerase II phosphorylated in vitro results in a polypeptide of $215 \mathrm{kDa}$. This intermediate-size subunit found in enzyme Ila corresponds to the primary gene product, and is considered to be in an intermediate state of phosphorylation (Dahmus, 1981).

The isolated mammalian RNA polymerase II0, IIa and IIb appear to have a very similar transcription activity. Once transcription is initiated, chain 
elongation can be carried out efficiently also by the proteolyzed form of the enzyme (RNA polymerase Ilb). A monoclonal antibody specific to RNA polymerase IIa, but not to the proteolyzed form Ilb as found to completely inhibit specific transcription in vitro and in injected oocytes (Thompson et al., 1989). This suggested that only the native form of the enzyme (Ila) participates in specific transcription.

The phosphorylated C-terminal domain is involved in the regulation of transcription. However, in vitro, in RNA-polymerase-dependent transcription extracts, RNA polymerase IIb which lacks the C-terminal domain, retains the ability to initiate transcription accurately suggesting that not all genes require the C-termınal domain for transcription complex formation (Thompson el al., 1989). It is proposed that the nonphosphorylated form IIa is required for initiation of transcription, whereas RNA chain elongation may be catalyzed by RNA polymerase II0 after phosphorylation of its C-terminal domain, thereby acting as the transcribing enzyme (Laybourn and Dahmus, 1989).

Accurate transcription depends on the recognition of a TATA element, which is part of the transcription initiation site about 25 base pairs upstream of the start point of transcription with some effect of sequences immediatcly surrounding the transcription initiation site, termed as initiator (Smale and Baltimore, 1989). Upstream elements of the promoter or upstream activation sites (UASs) are also observed to be important for in vitro transcription, although the 
amplitude of their effect is often smaller than that observed in vivo (Hen et al., 1982). Accurate transcription is not only dependent on the recognition of a TATA box by RNA polymerase B, but also on forming an initiation complex with other transcription factors, for example TFIID, TFIIA, TFIIB, TFIIE (Guarente and Bermingham-Mcdonogh, 1992). The initial step of TFIID binding to the TATA box is followed by the binding of TFIIA, TFIIB, RNA polymerase B and TFIIE respectively (see Diagram $A$ ). In the absence of the stimulation by activators which bind to the UAS, this pathway functions at a low level in basal transcription. Functional and structural homologs of TFIID were cloned from Schizosaccharomyces pombe, Drosophila, human and Archidopsis (Lewin, 1990). All of these contained a core region of great similarity at the carboxyl terminus, but divergent amino termini that were short in the yeast genes, and longer in the Drosophila and human genes.

Transcription assays using recombinant TFIID suggested that the activator Spl interacts with TFIID at its amino terminal domain, since Spl is unable to support activated transcription in the presence of recombinant TFIID which lacks this amino terminal domain (Peterson et al., 1990). In addition to activators, such as $\mathrm{Spl}$, which greatly influence transcription, the existence of coactivators has been inferred from in vitro transcription studies. These coactivators appear to be necessary for the interaction of the activators with the transcription initiation complex (Pugh and Tjian. 1990). 
Some specific activators are structurally conserved in eukaryotes. A region very similar to the DNA-binding domain of the yeast GCN4 protein, a global activator of genes that respond to amino acid starvation, was discovered within the sequence of the avian sarcoma virus oncoprotein Jun (Vogt et al., 1987). Yeast and mammalian cells have conserved on highly related transcriptional activators that bind to the same DNA sequence. For example, the mammalian serum response factor (SRF) activates the fos gene upon scrum starvation (Norman et al., 1988). A factor in yeast encoded by the MCMI gene was observed in vitro that bound to the same site as SRF (Herskowitz, 1989). MCMI itself appears to be a transcriptional activator, its binding site alone will drive expression of a TATA box reporter construct.

Another example for evolutionary conservation of upstream regulatory activator elements is the CCAAT box that is shared by yeast and mammalian cells. In yeast, a heteromeric complex, composed of HAP2, HAP3, and HAP4, which regulates the transcription of a large number of nuclear genes that are involved in the biogenesis of mitochondria (Forsburg and Guarente, 1989) was found to bind the CCAAT box. Similarily, the mammalian HeLa cell factor CPI, containing subunits $\mathrm{CP} 1 \mathrm{~A}$ and $\mathrm{CPIB}$, both required for DNA binding, is also a heteromeric complex that binds to the CCAAT box (Chodosh et al., 1988a). The subunits CP1A and CP1B can be exchanged with HAP3 and HAP2 respectively to restore DNA binding (Chodosh et al., 1988b). The CCAAT-binding factor 
from mouse and rat were purified and the cloned genes contain HAP2 and HAP3 subunits from the HAP complex (Maity et al., 1990; Hooft van Huijsduijnen et al., 1990).

The regulation and cellular role of these homologous activators has been greatly altered in evolution to accommodate the needs and complexities of different organisms. Basically, each of the conserved transcription factors appears to play a different regulatory role in yeast and in mammalian cells. Evolution thus has built on pre-existing factors and mechanisms by altering the response of transcriptional activators to signal transduction pathways. For instance, GCN4 is a regulator of amino acid biosynthesis genes in $S$. cerevisiae (Hinnebusch, 1984). In mammalian cells, Jun serves a role in transcription and the gene product is involved in activation of transcription in response to serum (Curran and Franza, 1988). Importantly, Jun and Fos can form a homodimers and heterodimers via their leucine zipper domains (Mitchell and Tjian, 1989) to provide a network of transcription factors. In the evolution of $S$. cerevisiae, the regulation of synthesis of GCN4 fell under an elaborate mechanism of transcriptional control in response 10 amino acid starvation (Hinnebusch, 1984). GCN4-binding sites are present in promoters for amino acid biosynthesis genes. In mammalian cells, the regulatory pathways are more extensively amplified and diversified to generate the Jun and activating transcription factor (ATF) families. In both yeast and mammalian cells, regulators are tailored to fit the needs of the organism as controlled by 
physiological signals in the case of the yeast, and increased complexity in the case of metazoans. Another example for homologous transcription factors are MCM1/SRF. In mammalian cells SRF responds to serum stimulation while a similar role is played by MCMI in the activation of yeast genes by mating pheromones.

\section{a.2. Translation and translational control of protein synthesis}

Protein synthesis is regarded as an integral part of the gene expression machinery since the expression of specific genes is under the control of proteins. Protein synthesis requires a series of preparatory steps and therefore depends on the collaboration of several classes of RNA molecules and regulatory proteins. Translation is usually considered to have three stages: initiation, elongation and termination (Moldave, 1985). Each stage involves important biochemical events, catalyzed on the ribosomes which are large complexes of RNA and protein molecules.

\section{Initiation of translation}

The first event in inititation is the attachment of a free methionine molecule to the end of tRNA ${ }^{\text {met }}$ by a specific methionyl-tRNA synthetase. Methiony!tRNA $^{\text {met }}$ then binds the AUG initiation codon on the mRNA, and initiation factors (IF $F_{2}$ in prokaryotes and $\mathrm{eIF}_{2}$ in eukaryotes), Met-tRNA ${ }_{1}^{\mathrm{mut}}, \mathrm{GTP}$ and the small 
subunit of the ribosome ( $30 \mathrm{~S}$ in prokaryotes, $40 \mathrm{~S}$ in eukaryotes) to form an initiation complex (30S initiation complex in prokaryotes and $40 \mathrm{~S}$ initiation complex in eukaryotes) in the cytoplasm. The large ribosomal subunit (50S in prokaryotes, $60 \mathrm{~S}$ in eukaryotes) joins the initiation complex in order to catalyze peptide bond formation, and a second amino acid is correctly bound into proper position to the RNA on the ribosome. There are two ribosomal sites that can be occupied by IRNA molecules: the aminoacyl-tRNA binding site or 'A' site binds the incoming IRNA molecule that is to contribute a new amino acid to the growing peptide; and the peptide-tRNA binding site or ' $\mathrm{P}$ ' site which binds a peptidyl-IRNA complex and holds the tRNA molecule to all amino acids linked to the end of the polypeptide chain. The initiation complex is ready to begin synthesis of the peptide chain.

\section{Elongation of peptides}

A new aminoacyl-tRNA binds to the ribosome at the ' $A$ ' site by the activation of specific aminoacyl-tRNA synthetases. After that, aminoacyl-tRNA carrying a specific amino acid, binds to the appropriate codon in the mRNA through complementary base-pairs with the mRNA. During translation in prokaryotes, a protein complex called $\mathrm{Tu}$-Ts catalyses the binding of each aminoacyl-tRNA to the ribosome. An activated Tu-GTP complex binds to the 


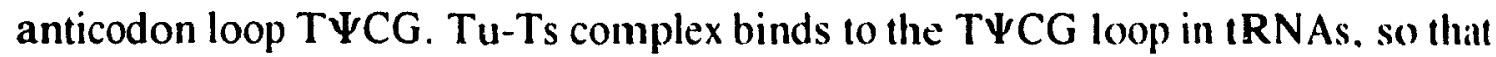
tRNA can associate with the ribosomes. This binding reaction is accompanied by the hydrolysis of the GTP molecule. As Ts protein rejoins GDP-Tu and reactivates it, it forms a new complex of GDP-Tu-Ts, and the cycle is continued. The whole elorigation factor complex is bound to the ribosome, the hydrolysis of GTP yields the energy for translocation, peptidyl-IRNA vacates the A site and shifts to the $\mathrm{P}$ site in the process.

During the elongation step of protein synthesis clongation factors (EF) bind to both the amino acid end of tRNAs and to a molecule of GTP. The bound elongation factor allows pairing of codon-anticodon and, step by step, an!ino acids incorporation into the polypeptide chain. The initial codon recognition triggers the elongation factor to hydrolyse the GTP bound to it. The factor then dissociates again from the ribosome (see Diagram B).

Elongation factors are protein factors responsible for the polypeptide chain elongation in cells. In eukaryotic cells, there are two groups of elongation factors, eEF-1 and eEF-2, corresponding to the prokaryotic EF-Tu - Ts complex and EF-G respectively. eEF-1 consists of three subunits designated $\mathrm{eEF}-\mathrm{I} \alpha, \mathrm{eEF}-1 \mathrm{~B}$ and eEF-1 $\gamma$, of which eEF-1 $\alpha$ corresponds to the prokaryotic EF-Tu and the eEF-1 $13 \gamma$ complex to the prokaryotic EF-Ts (Safer, 1989). The role of EF-Ts in the polypeptide elongation reaction is to accelerate the dissociation of EF-Tu - GDP complex (Arai et al., 1972). In yeast, another factor, the factor 3 for 
polyphenylalanine synthesis is required (Dasmahapatra and Chakraburtty, 1981). Radioimmune assays and GDP binding showed that EF-Tu is a major protein in E. coli (Furano, 1975) similar to EF-1 $\alpha$ present ii: rabbit reticulocytes (Slobin, 1980). In biochemical assays on cell-free extracts of yeast, Saccharomyces cerevisiae, two species of elongation factor EF-1 (EF-1 $\alpha$ and EF-1H) have been isolated and purified. Yeast EF-l $\alpha$ is a single polypeptide with a molecular weight of $50 \mathrm{kDa}$ and an isoelectric point at $\mathrm{pH}$ 8.9. Yeast EF-1 H has a molecular weight of $200 \mathrm{kDa}$ and an isoelectric point at around pH 5.5 (Saha and Chakraburtty, 1986) .

\section{Termination of translation}

Termination factors are proteins that recognize the termination codon which signals the release of the peptidyl-tRNA complex. There are three termination codons UAG, UAA and UGA. Upon the signal from the termination factor, the ribosome arrives at UAG codon and the translation is completed. Hydrolysis of peptidyl-tRNA on the ribosome releases the completed polypeptide, and the last IRNA, and the two ribosomal subunits separate. They are ready to start the whole cycle over again. 


\section{Regulation of translation}

Several parameters will affect the rate of protein synthesis. For specific protein synthesis, the limiting components are the cytoplasmic concentration of the particular mRNA and their specific activities. These activities are determined by the intrinsic activity of the mRNA and by trans-acting elements. The intrinsic efficiency, whereby a mRNA is translated, depends on the structure of the specific RNA. Four features appear to be important.

(1) The presence and accessibility of a $5^{\prime}-m^{7} \mathrm{G}$ cap structure enhances mRNA translation.

(2) Initiation of translation depends on the stability and position of the mRNA structure. Very little is known about how proteins in mRNPs influence higherorder structures and thus the process of translation (Hershey, 1991).

(3) The placement and context of the AUG initiation codon affects translational efficiency. A mRNA with an upstream AUG and a strong consensus sequence for preproinsulin inserted in the 5'-UTR (untranslated region) translated poorly. However, when a termination codon is introduced in frame and distal to the upstream AUG will increase the efficiency of the translation. (Kozak, 1984).

(4) The presence and length of poly(A) tails at the 3'-terminus contribute to translational efficiency (Jackson and Standart, 1990). Most mammalian mRNAs are polyadenylated soon after transcription in the nucleus, and carry $200-250$ adenylate residues at their 3'- terminus as they are transported into the cytoplasm. 
The poly(A) tails are thought to affect both mRNA stability and translational efficiency. (Bernstein et al., 1989). The poly(A)-poly(A) binding protein complex is a major determinant of mRNA stability in vitro. Analysis of mRNA degradation in a cell-free system showed that the poly(A) tail is degraded only when it is naked and not associated with poly(A) binding proteins.

For global protein synthesis, the limiting parameters are more difficult to identify. In general, ribosomal levels appear to define the overall capacity of a cell to synthesize proteins. Phosphorylation/dephosphorylation of numerous protein components of the translational apparatus appears to play an important role in controlling the overall rate of protein synthesis in mammalian cells (Hershey, 1989). Phosphorylation of a number of initiation factors, namely elF2B, elF-3, elF-4B and elF-4F, as well as ribosomal protein S6, correlates with activation of protein synthesis in vivo or with increased factor activity in vitro. eIF- $4 \mathrm{~F} \alpha$, is the relatively low-abundance cap-binding protein within the eIF-4F group, which is phosphorylated in vivo primarily at Ser53. The same site is phosphorylated in vitro by protein kinase C (Tuazon et al., 1989), where the preferred substrate is the eIF-4F complex rather than the free eIF-4F $\alpha$ subunit (Tuazon et al., 1990). Phosphorylation of elF-4F $\alpha$ does not appear to alter its affinity for $\mathrm{m}^{7} \mathrm{G}$ cap structures, however, numerous correlative data link phosphorylation and the active state of the factor. 
The ribosomal protein $S 6$ is a phosphoprotein found in the 40S subunit of the eukaryotic ribosome. It occupies a position in the $40 S$ subunit within the mRNA-binding. S6 is phosphorylated in vivo on five serine residues near the Cterminus of the protein. Recently. S6 specific protein kinases have been purified from a variety of cell types (Erikson and Maller, 1986) and a cDNA encoding a mouse S6 kinase has been cloned (Kozma el al., 1990). A complex network of kinases and phospnatases appears to be involved in establishing the phosphorylation level of S6.

eIF-4B, like S6, is phosphorylated at multiple sites on serine residues. It is phosphorylated in vivo when cells are treated with serum or tumor-promoting phorbol esters (Morley and Traugh, 1990), and in vitro by the mammalian or Xenopus S6 kinases as well as by protein kinase C (Tuazon et al., 1990).

Another initiation factor eIF-3 is composed of eight different polypeptides, and phosphorylation of one of these is enhanced by insulin and phorbol esters (Benne et al., 1978). However, no report implicates phosphorylation of these subunits in translational control.

Inhibition of protein synthesis may be caused by enhanced phosphorylation of two soluble factors elF-2 and eEF-2. The phosphor tation of the $\alpha$-subunit of the eIF-2, eIF- $2 \alpha$, correlates with inhibition of protein synthesis and results in loss of factor activity in vitro. Phosphorylated eIF-2 - GDP bunds more tightly to eIF-2B, but does not exchange GDP for GTP. Since elF-2 has a higher cellular 
level than eIF-2B, only a portion of eIF-2 needs to be phosphorylated in order to inhibit cIF-2B activity. However, some results indicated that inhibition of protein synthesis does not always occur when eIF- $2 \alpha$ is phosphorylated. Therefore, repression of eIF- $2 \alpha$ phosphorvlation may be modulated by modification of eIF2B structure and activity (Dholakia and Wahba, 1989).

A second phosphorylation pathway for inhibition of protein synthesis involves the elongation factor eEF-2. Phosphorylation of EF-2 is catalyzed by a $\mathrm{Ca}^{2+} /$ calmodulin-dependent protein kinase called $\mathrm{Ca}^{2+} /$ calmodulin-dependent protein kinase III or EF-2 kinase. EF-2 phosphorylation in vitro occurs at three threonine residues (Thr-53, Thr-56, Thr-58) in the N-terminal part of the molecule (Ovchinnikov et al.,1990). Phosphorylated eEF-2 binds to the $80 \mathrm{~S}$ ribosomes but is unable to catalyse the translocation reaction with GTP in vitro (Ryazanov and Davydova, 1989).

\section{b. The Cell Cycle}

Eukaryotic cells divide in order to reproduce themselves. They proliferate through a process called mitotic division. Mitotic division involves a complex progression of events which ultimately result in the division of a single cell into two daughter cells (mitosis). This progression is referred to as the cell cycle. (Bascrga, 1985). 
There are four phases in the cell cycle $\left(M, G_{1}, S\right.$ and $\left.G_{2}\right)$. During mitosis itself ( $M$ phase), a single cell divides into two daughter cells. In the $G_{1}$ phase, cells usually grow in size and prepare for DNA synthesis. During S phase, cells duplicate their DNA. In $G_{2}$ finally, the period between $S$ phase and the next $M$ phase, DNA synthesis ceases and the cells prepare for mitosis.

After several cell divisions, some cells often leave the cell cycle traverse during the $G_{1}$ phase and stop proliferating. These are mostly terminally differentiated cells that are said to be quiescent or in a $G_{0}$ phase. Upon external stimuli $\mathrm{G}_{0}$ phase cells are often able to reenter the cell cycle. For example, induction to re-enter the cell cycle traverse can be accomplished by serum stimulation of in vitro cultures. There appears to be a direct correlation between the amount of time needed to re-enter the cell cycle and the length of time spent in the quiescent state (Hayflick, 1965). Nevertheless, the $G_{0}$ phase is not a toxic state for the cells. Although the cells are not replicating, they still maintain active metabolic functions.

The liver contains many cells in $\mathrm{G}_{0}$ or quiescent state. It has been shown that about $90 \%$ of hepatocytes are capable of metabolic activity despile absence of cell division. Hepatocytes in situ can be induced to re-enter the cell cycle by an apropriate stimulus. An example of such a stimulus is $70 \%$ partial hepatectomy, after which the hepatocytes in the remaining tissue leave the 
quiescent state, re-enter the cell cycle, synthesise DNA and proliferate to regenerate the lost tissue (Fabrikant, 1968).

\section{b.1. Genetic and molecular control of mitosis}

Cell division in eukaryotes has three transition points: entry into mitosis, exit from mitosis and START (Murray, 1989). START is defined in yeast as the point prior to which cells can be diverted to leave the cell cycle traverse and to enter the mating pathway; but after START has been passed, cells are committed to initiating DNA synthesis ( $\mathrm{S}$ phase). Entry into $\mathrm{M}$ phase is controlled by several parameters such as time, cell mass, growth rate, and the completion of chromosome replication. Experiments using natural or induced mutations in the fission yeast Schizosaccharomyces pombe, or experiments taking advantage of the meiotic arrest of Xenopus or starfish oocytes (Lohka, 1989), have led to the identification and characterization of cellular components that regulate this phase of the cell cycle.

Originally identified as the product of the cdc2 gene of the fission yeast Schizosaccharomyces pombe and the CDC28 gene in the budding yeast Saccharomyces cerevisiae, phosphorylated protein $34\left(\mathrm{p} 34^{\mathrm{cdc} 2}\right)$ is now known to be the catalytic subunit of the mitosis-inducing protein kinase known as maturation promoting factor (MPF) or growth-associated H1 kinase (Murray, 
1988). In addition to $\mathrm{p}^{\mathrm{id} 4^{2}}$, MPF contains cyclins which accumulate continuously throughout the cell cycle but are destroyed during mitosis.

Intially MPF was purified from Xenopus, and the fraction with the highest MPF activity was found to be associated with two proteins of about $32 \mathrm{kDa}$ and $45 \mathrm{kDa}$ (Lohka et al., 1988). This fraction contained a protein kinase activity able to phosphorylate the $45 \mathrm{kDa}$ protein. The smaller protein, with a molecular weight of $32 \mathrm{kDa}$, has been identified as the equivalent to $\mathrm{p} 34^{\text {cd.2 }}$ found in yeast. The other component of MPF is a cyclin. Two classes of cyclins, A and B, have been distinguished which differ slightly in a central region; the functional significance of these differences however is unclear.

Protein phosphorylation and dephosphorylation, are important control events during interphase and the entry into $\mathbf{M}$-phase, and, in the latter case, control the activation of the $\mathrm{p} 34^{\mathrm{d} 2}$ protein kinase and its association with cyclin. Dephosphorylation of a single tyrosine residue, Tyr15, activates the $\mathrm{p} 34^{\text {wh } 2}$ and facilitates entry into mitosis (Gould and Nurse, 1989). A simple model which has been applied to all eukaryotes suggests that $\mathrm{p} 34^{\text {di2 } 2}$ kinase activity is inhibited during interphase when tyrosine 15 is phosphorylated at an ATP hinding site. At the $\mathrm{G}_{2} / \mathrm{M}$ boundary, this phosphate group is removed allowing kinase activity to appear, which in turn causes cells to enter M-phase. After mitosis, p34 kinase is phosphorylated again which renders this protein inactive. This kinase inactivation is accompanied by cyclin degradation which occurs as cells exit from mitosis; 
disruption of the $\mathrm{p} 34^{\text {cdt2 }}$ cyclin complex could potentiate $\mathrm{p} 34^{\mathrm{cdc2}}$ kinase inactivation (see Diagram C).

The control mechanisms regulating mitosis in fission yeast involve at least four gene functions which act in concert. The gene products of $c \mathrm{cdc} 2^{+}, \operatorname{cdc} 25^{+}$, weel $1^{+}$and $n i m 1^{+}$act in a network to determine the timing of mitosis during the cell cycle (Russell and Nurse, 1986; Simanis and Nurse, 1986; Russell and Nurse, 1987a; Russell and Nurse, 1987b). One pathway of the mitotic regulatory network is inhibitory and includes the wee $1^{+}$gene product, which is a protein kinase. The second pathway is activatory through the $\mathrm{cdc} 25^{+}$gene product, a protein of $67 \mathrm{kDa}$ which is required to initiate mitosis, and the niml ${ }^{+}$gene product. Cdc25 ${ }^{+}$either inhibits a kinase acting on p34 or activates a phosphatase acting on $\mathrm{p} 34$. The balance of the two pathways regulate the action of $\mathrm{p} 34^{\text {dc2 }}$, by advancing or delaying onset of mitosis (Russell \& Nurse, 1987a). The nim $1^{+}$ (new inducer of mitosis) is the first dose-dependent mitotic inducer identified as a protein kinase homolog. Increased $n i m 1^{+}$expression rescues mutants lacking the mitotic inducer $\operatorname{cdc} 25^{+}$and advances celis into mitosis at a reduced cell size; loss of niml ' cielays mitosis until cells have grown to a larger size. nim $1^{+}$is a negative regulator of the wee ${ }^{+}$mitotic inhibitor (Russell and Nurse, 1987b). Weel ${ }^{+}$acts as a dose-dependent inhibitor of mitosis, functioning in opposition to the inducer cdc25+ (Russell and Nurse, 1987a, and see Diagram D). 


\section{b.2. Genetic and molecular control of S-phase (DNA synthesis)}

One protein which regulates cell cycle progression in S-phase is the proliferating cell nuclear antigen (PCNA), an acidic nuclear protein witl a molecular weight of $36 \mathrm{kDa}$. The rate of PCNA synthesis is very low in quiescent cells and increases several-fold after serum stimulation shortly before DNA synthesis. In synchronized cell cultures, the level and distribution of PCNA oscillates throughout the cell cycle. PCNA is highly accumulated in the nucleolus late at $G_{1}$ and in early $S$ phase and decreased at the border between $G_{2}$ and $M$ phase (Mathews et al., 1984; Sadaie et al., 1986).

Immunofluorescence studies of the distribution of PCNA during the cell cycle have revealed dramatic changes in its nuclear localization during the $S$ phase (Celis and Celis, 1985). It appears to be located in replicon clusters during DNA synthesis. This suggests that PCNA is tightly associaled with sites of DNA replication. Subsequently, PCNA has been shown to be an auxiliary protein for DNA polymerase $\delta$ which is necessary in processive leading strand DNA synthesis (Tan et al., 1986). However, a PCNA-independent form of DNA polymerase $\delta$ was also isolated from calf thymus under conditions which minimize proteolysis (Focher et al., 1989). PCNA could not stimulate PCNA-independent calf thymus DNA polymerase $\delta$ after any step of the isolation procedure. This enzyme is highly processive and very efficient in replication of natural primed single-stranded DNA in the absence of PCNA. 
DNA polymerase III from Saccharomyces cerevisiae is analugous to the mammalian PCNA-dependent DNA polymerase $\delta$, and both polymerases had increased synthetic activity on poly(dA).oligo(dT) in the presence of calf thymus PCNA (Bauer and Burgers, 1988). Yeast PCNA and calf thymus PCNA are equally active in stimulating DNA synthesis by DNA polymerase III, primarily by increasing the processivity of the DNA polymerase.

More cvidence that PCNA is directly involved in controlling DNA synthesis during S-phase came from studies, in which Balb/c 3T3 cells were exposed to antisense oligonucleotides of PCNA. In these cells both DNA synthesis and mitosis were completely suppressed, whereas corresponding sense oligonucleotide had no effect (Jaskulski et al., 1988a). Balb/c 3T3 cells were further used to determine whether a common regulatory mechanism exists that controls the expression of gene products that are part of the DNA synthesizing machinery, like PCNA and thymidine kinase (TK). TK is an enzyme in the salvage pathway of thymidine. TK enzyme activity and mRNA steady-state levels increase sharply when cells enter S phase. PCNA and TK mR'JA levels were therefore studied in response to different growth factors. Besides some kinetic differences between PCNA mRNA and TK mRNA induction in the response to serum and to platelet derived growth factor, the expression of PCNA responds to epidermal growth factor, while TK mRNA does net. The expression of both 
enzymes, however, requires protein synthesis, indicatirg that this expression is regulated by other growth factor-regulated genes (Jaskulski el al., 1988b).

\section{b.3. Cell cycle arrest during early $G_{1}$ (quiescence)}

The $G_{1}$ phase of the cell cycle is defined as the time interval between the readily observable events of mitosis and the initiation of DNA synthesis ( $S$ phase). The duration of $G_{1}$ is different between various cell types. In the case of short $G_{1}$ intervals, the essential biochemical events for controlling cell cycle progression can begin during the previous cycle, at the same time and in the same cell as other events such as DNA synthesis or preparation of mitosis (Baserga, 1985). Cells in vivo, for example hepatocytes and neurons, can remain healthy for very long periods of time in the nonproliferating or quiescent state, often called $\mathrm{G}_{0}$. Cells in culture can also be in a $\mathrm{G}_{0}$ state. $\mathrm{G}_{0}$-phase-arrested cells have an unduplicated DNA content, as do cycling cells in $G_{1}$ phase (Pardec, 1989). In culture, $G_{0}$ cells when stimulated by the additional of scrum, can reenter the cell cycle. Thus, $G_{0}$ cells will not enter the cell cycle unless they receive an appropriate exogenous signal, such as serum growth factors or lack of contact inhibition.

When cells were kept for long periods of time in the $G_{0}$ phase under serum starvation, rates of protein synthesis and number of polysomes decreased (Duncan and Hershey, 1985a,b). As the growth rate decreased, the synthesis of some 
initiation factor proteins, particular eukaryotic initiation factor (eIF)-3 subunits, became depressed. Stimulation of serum-starved cells with addition of fresh serum recruits most inactive ribosomes and mRNAs into polysomes, but the levels of most initiation factor mRNAs do not change when cells re-enter the cell cycle. Under the condition of serum starvation, (eIF)-3 is phosphorylated at the transition from $G_{1}$ to $S$ phase. This observation suggests that phosphorylation of this initiation factor is responsible for the repression in a growth-arrested cell.

Two distinct states of growth-arrest in cultured WI-38 cells have been identified depending on the duration of serum depletion (Owen et al., 1989). Short term or "early" growth-arrest, occurs during the first 7-10 days following cessation of DNA synthesis and mitosis. It is characterized by few biochemical changes compared to actively proliferating cells. In cells arrested for 10-20 days, termed long-term-growth-arrest, there is a decreased overall protein and DNA content, an enhancement in collagen and fibronectin levels and a deterioration of EGF-dependent signal transduction pathways (Owen et. al., 1990). Once the cells are later stimulated to re-enter the cycle, expression of growth-associated genes turned on in late $G_{1}$ such as thymidine kinase, ornithine decarboxylase and vimentin is retarded (Owen et. al., 1990). Although WI-38 cells do cease to incorporate lhymidine and to divide under confluent culture conditions, these "quiescent" cells undergo changes, are metabolically active, and certainly do not deteriorate grossly. 
Genes specifically expressed in growth arrested cells (gas: growth arrestspecific gene) have been identified by screening of a cDNA library for cDNAs corresponding to mRNAs which are expressed in growth-arrested cells (Schneider et al., 1988). Six cDNA clones were identified ranging in size from 0.8 to $10 \mathrm{~kb}$. Two cell lines transformed by viral onc genes did not express two of the six gas genes. Expression of these $\mathrm{G}_{0}$-specific genes is negalively regulated by the presence of serum and by growth factors: some of them are rapidly downregulated within 2-3 hours after induction of growth; whereas others take longer (6-10 hours) before downregulation is observed. The gas/ gene product is cell cycle controlled and it accumulates again during the $S$ phase of synchronized cultures. gas 1 and gas 2 mRNAs are found in lung tissue. When gas gene expression is suppressed, by addition of serum, results in an overall increase in protein synthesis in the cell. This indicate that gas genes function to suppress gene by a mechanism currently unknown. The expression of gas genes was shown to be sensitive to the drug 2-aminopurine which inhibits protein kinases. The fact that the level of gas gene mRNA was reduced by serum, and that nucluar transcription of gas $-2,-3$ and -5 was observed in serum-stimulated cells, indicates that regulation takes place at the transcriptional level (Circarelli et al., 1990). The protein encoded by the gas 3 gene showed similarity to a mitochondrial oxyreductase and can be obtained by in vitro translation in the presence of dog pancreatic microsomes (DPM) when extracted with Triton X-114. The gas3 
product was found only in the detergent-soluble phase, suggesting that the gas 3 gene product is a transmembrane glycoprotein (Manfioletti et al., 1990).

\section{b.4. Cell cycle arrest at late $G_{1}$ (senescence)}

In contrast to cellular quiescence, in which cells are arrested in early $G_{1}$, or thought to be in $G_{0}$ of the cell cycle, cells arrested at late $G_{1}$ are thought to be senescent (Baserga, 1985). Whereas $G_{0}$ cells are readily able to re-enter the cell cycle upon stımulation with growth factors, senescent cells are unable to go back into cell cycle, regardless of the presence of external stimuli. Weissmann and Minot (1882) and other biologists speculated that senescence is the price a cell pays for differentiation. Hayflick and Moorhead (1961) proposed a new view that aging was a cellular as well as an organismic phenomenon, and that perhaps the loss in functional capacity of the aging individual reflected a summation of the Ioss of critical functional capacities of individual cells. They also pointed out that unless transformation occurred at some point in the life history of the cell, senescence always resulted. When Hayflick attempted to culture strains of human diploid fibroblasts (HDF), these cells eventually degenerated and died (Hayflick, 1965). This body of work supports the idea that there is a limited replicative potential for human cells in vitro and this limit resembles their lifespan in vivo. It appears therefore that cells may count the number of population doublings to a critical limit and then stop dividing (Goldstein and Singal. 1974). During in 
vitro aging, the thymidine labelling index, a measure of DNA division, reached about $80-90 \%$ in early passage cultures. A gradual decrease of the labelling index followed as more cells became senescent during subsequent passage (Christofalo and Sharf, 1973; Harley and Goldstein, 1980).

Flow cytometric measurements of HDF indicated that there are differences in morphology and biochemical characteristics between cells in the $\mathrm{G}_{1}$-senescent and the $\mathrm{G}_{0}$-quiescent states of the cell cycle. Senescent HDF are larger than cycling cells at $G_{1}$, and senescent cells have a lower nucleocytoplasmic ratio than those that are cycling (Sherwood et al, 1988). Moreover, in senescent HDF, nuclear size and the amounts of RNA, protein, glycogen, lipids and lysosomes are increased. The amount of DNA, however, decreased in both $G_{1}$ and $G_{2}$ phases of the cell cycle.

It is suggested that senescence may involve disrupting cell cycle control, in addition to blocking DNA synthesis initiation (Goldstein, 1990). Indeed, it is also suggested that beyond initiation and completion of DNA synthesis, cellular senescence also affects chromosome condensation, pairing, and segregation as well as nuclear cleavage and cytokinesis (Sherwood et al., 1988).

Comparison of the proliferative capacities of cells grown in vitro from donors of different ages suggested that certain aspects of in vivo aging are also seen in cell culture. Hayflick (1965) showed that the number of population doublings in cultures of adult-derived lung fibroblasts is less than that in cultures 
derived from human embryos. Martin and coworkers (1970) studied cultured fihroblasts from skin biopsies and found that as the age of the donor increased, the life span of the cultured cells decreased. There is therefore an inverse relationship between the in vitro cellular lifespan and the age of donor. Whether the limit of the lifespan is genetically predetermined or environmentally induced is controversial. In vitro aging of human fibroblasts may be caused by damage at the level of the genome. Treatment of adult and fetal lung-derived fibroblasts with low doses of ionizing radiation resulted in an increase in chromosomal abnormalities in the adult cells, whereas no change in the fetal cell chromsomes was detected (Bourgeois et al., 1981).

The culture of HDF has been widely used as an in vitro model for aging. Grove and Cristofalo (1977) found that the cell cycle time increased during in vitro aging due to elongation of the $G_{1}$ phase. They hypothesized further that these normal human fibroblasts became senescent, and produced an inhibitor of DNA synthesis.

Experiments have been performed to produce heterokaryons between senescent and young cells. These were first performed by Norwood et al. (1974, 1975) and later confirmed and extended by Stein and Yanishevsky (1979; Yanishevsky and Stein, 1980). When quiescent or senescent cells fused with replicating ones, entry into $S$ phase and the initiation of DNA synthesis was inhibited in the young cell nuclei of the fused cells. These results suggested that 
senescent and quiescent HDF may share a common inhibitory protein responsible for the cessation of proliferation (Stein and Yanishevsky. 1981).

To determine whether the Simian papovavirus SV40 could induce proliferation and morphological transformation in senescent cells, prolifirating and senescent WI-38 fibroblasts where infected with SV-40 or fused with lethally irradiated cells of a continuous line VA-13 (containing the SV-40 genome). Whereas the proliferating cells underwent morphological changes, showed accelerated proliferation and subsequently ceased proliferation, senescent WI-38 cells showed neither accelerated proliferation nor morphological changes by infection or by infusion. Genes responsible for the morphological changes do not appear to be responsible for the property of continuous proliferation (Matsumura et al., 1980).

Cell fusion experiments had suggested that cellular aging was a genetically programmed process. Hybrids obtained from fusion of normal cells with immortal cells exhibited limited division potential (Pereira-Smith and Smith, 1988). These results indicated that the phenotype of cellular senescence was dominant and that immortality resulted from recessive changes in normal growth regulatory genes. When senescent cells were enucleated and the derived cytoplasts were fused with young cells and it was found that the cytoplast was as effective as the whole cell in blocking initiation of DNA synthesis in the young cells (Drescher-Lincoln and Smith, 1984). 
Cells transformed with carcinogen were not able to induce DNA synthesis in the nuclei of senescent HDF in the fused cells and the transformed nuclei were inhibited from entering S phase. (Stein et al., 1982). However, when senescent cells were fused with immortal cell lines containing DNA tumor virus, the immortal lines were able to overcome the inhibition of DNA synthesis. The heterokaryons not only synthesized DNA in their own nuclei, but also induced DNA synthesis in the nuclei of the senescent cell.

When a plasma membrane-enriched fraction of senescent HDF was added to young cells, entry into $S$ phase was inhibited, suggesting that senescent HDF contains an inhibitor of DNA synthesis (Stein et al.,1982). This inhibitor appears to be a glycoprolein, and is resistant to elimination following serum stimulation of senescent HDF However, when quiescent young cells are stimulated to grow by addition of serum the inhibitory activity disappeared from these young HDF at late $G_{1}$ phase.

Lumpkin et. al. (1986) found high abundance of anti-proliferative mRNA in senescent human diploid fibroblasts. Microinjection of the poly (A) ${ }^{+}$fraction of mRNA isolated from senescent cells into young cells blocked DNA synthesis. The non-poly $(A)^{+}$fraction. RNAse treated poly $(A)^{+}$fraction, or RNA isolated from young cells were unable to block the initiation of DNA synthesis. This suggests that senescent cells may produce a gene product capable of inhibiting 
initiation of DNA synthesis, as assayed by its effect on young proliferationcompetent human fibroblasts.

A tempting interpretation of all of these experiments is that senescent cells fail to proliferate because of the production and the action of an inhibitor of DNA synthesis. Quiescent and senescent fibroblasts showed similar basal and seruminducible expression of the c-myc and c-H-ras proto-oncogens, the gene products of which stimulate proliferation and are required to leave $G_{0}$ (Rittling et al., 1986). c-fos, which in quiescent cells is induced early in $G_{0} / G_{1}$ interval and stimulates cell to proliferate (Müller et al., 1984), is repressed at the level of transcription in senescent cells (Seshardi and Campisi, 1990). Growth-related cfos proto-oncogene may be under dominant repression in senescent cells.

With the recent discovery of tumor suppressor genes, and negative regulators of growth, studies in aging begin to merge with those of carcinogenesis. For example, RB, the retinoblastoma gene product, is a nuclear phosphoprotein. RB is active as an unphosphorylated form in quiescent cells but becomes phosphorylated (inactive) when cells are rapidly proliferating; suggesting that phosphorylation of the RB gene product may be necessary for entry into $S$ phase (Chen et al., 1989; DeCaprio et al., 1989). Both seriescent and quiescent human diploid fibroblasts (HDF) contain the unphosphorylated form of the retinoblastoma protein. After serum stimulation, the RB protein in senescent HDF 
can not be phosphorylated in correlation with the failure to enter S-phase (Stein et al., 1990).

\section{b.5. Statin}

In an attempt to identify genes and proteins that are specifically expressed in growth arrested cells, Wang (1985a) raised monoclonal antibodies against detergent insoluble fractions of senescent HDF. Two of these antibodies, mAb $\mathrm{S} 30$ and $\mathrm{mAb} \mathrm{S} 44$, identified an antigen called statin present in cells that are in the $\mathrm{G}_{0}$-quiescent as well as in the $\mathrm{G}_{1}$-senescent state. Statin is a $57 \mathrm{kDa}$ protein predominantly associated with the nuclear envelope in non-proliferating cells, but not in their dividing counterparts (Wang, 1985b). Statin is expressed when young cultured fibroblasts are deprived of serum or grown to confluency. When these cells are induced to proliferate by addition of fresh medium or by sparse plating, statin is lost 12-14 hours before entry into $S$ phase. This result indicates that statin synthesis takes place in quiescent cells, then declines rapidly when cells are induced to proliferate (Wang and Lin, 1986). In senescent HDF which are unable to re-enter the cell cycle upon serum stimulation, expression of statin persists (Wang, 1989).

The specific expression of statin in quiescent cells has also been shown to exist in differentiated tissue in situ. Immunohistochemistry on various tissues showed that the epithelial cells covering the villi of the small intestine 
(Bissonnette et al., 1990), the superficial layer of epidermis, the hair sheath, the tongue, a subpopulation of fibroblasts in the dermis, chondrocytes (Wang and Krueger, 1985), hepatocytes (Sester et al., 1989), neurons (Schipper and Wang, 1990) and cardiac muscle cells express statin (Connolly et al., 1988)

In order to obtain a molecular probe for statin, mAbs S30 and S44 were used to screen a lambda gt 11 expression library of rat brain. A cDNA clone, designated SI was isolated, sequenced and characterized (Wang et al., 1989). The nucleotide sequence of $S 1$ revealed $78 \%$ homology with a cDNA for human elongation factor one alpha (Hum EF-1 $\alpha$ ). Even more strikingly, SI and EF-I $\alpha$ share $92 \%$ homology when the predicated amino acid sequences are compared. The two sequences differ at their amino and carboxyl termini with less than $20 \%$ in homology.

\section{General objectives}

The high similarity between the SI cDNA and human EF-I $\alpha$ suggested that statin or $\mathrm{pSI}$ may be a member of the EF-1 $\alpha$ gene family. This was surprising in light of the observation that statin is a nuclear component, whereas EF-I $\alpha$ resides in the cytoplasm and functions in the process of peptide elongation during message translation.

In order to further elucidate the relationship between $\mathrm{pSI}$ and statin and between $\mathrm{pSl} / \mathrm{statin}$ and $\mathrm{EF}-\mathrm{l} \alpha$ it was utmost importance to obtain probes which 
allow for cellular and functional characterization of these proteins. The general objective of this study therefore was to provide tools in the form of antibodies which would help us to distinguish between pS1, statin and EF-1 $\alpha$. These tools are necessary in order to learn more about the cellular controls involved in fundamental processes such as protein synthesis, cell cycle and aging.

\section{Specific objectives}

In order to generate antibodies specific to $\mathrm{pS} 1$, it was first necessary to construct a plasmid vector which could be used to transform bacteria for the production of the recombinant S1 protein. To express $\mathrm{pS} 1$ in bacteria I chose the glutathione S-Iransferase (GST) gene fusion system in which commercially available plasmid vectors containing the GST gene and a trp-lac promoter (De Boer et al., 1983) were ligated with the S1 cDNA. This gene fusion system was chosen because the GST gene with the promoter drives the expression of the inserted SI cDNA, once transformed into $E$. coli bacteria. The resulted fusion protein containing GST and recombinant $\mathrm{S} 1$ protein $(\mathrm{rpS1})$ can then be purified from the bacterial lysates by affinity chromatography with glutathione bound to sepharose beads or by SDS-polyacrylamide gel electrophoresis (SDS-PAGE). The fusion protein can then be cleaved into two portions with thrombin protease separating the GST from rpS1. The proteins obtained can be analyzed by SDSPAGE. 
A second objective was to generate polyclonal antibodies against the purified rpS1 by immunizing rabbits and to verify that the antiserum thus produced indeed recognized the expressed protein by western blot analysis. 


\section{Diagrams}


Diagram A. Diagramatic model of the basic transcriptional complex. The TATA box is found at most promoter of genes transcribed by RNA polymerase II and is bound by the general transcription factor TFIID (D) which is located about 25 base pairs upstream of the start point (arrow). Depicted is the pathway of assembly of the transcriptional complex by general factors such as TFIIA (A), TFIIB (B), and TFIIE (E) at the promoter, including the RNA poymerase (pol II). (After Guarente and Bermingham-Mcdonogh, Trends in Genet. 8: 27-32, Fig.1, 1991). 
$\begin{array}{lllll}-50 & -30 & -10 & +10 \quad+30 \text { base pairs }\end{array}$
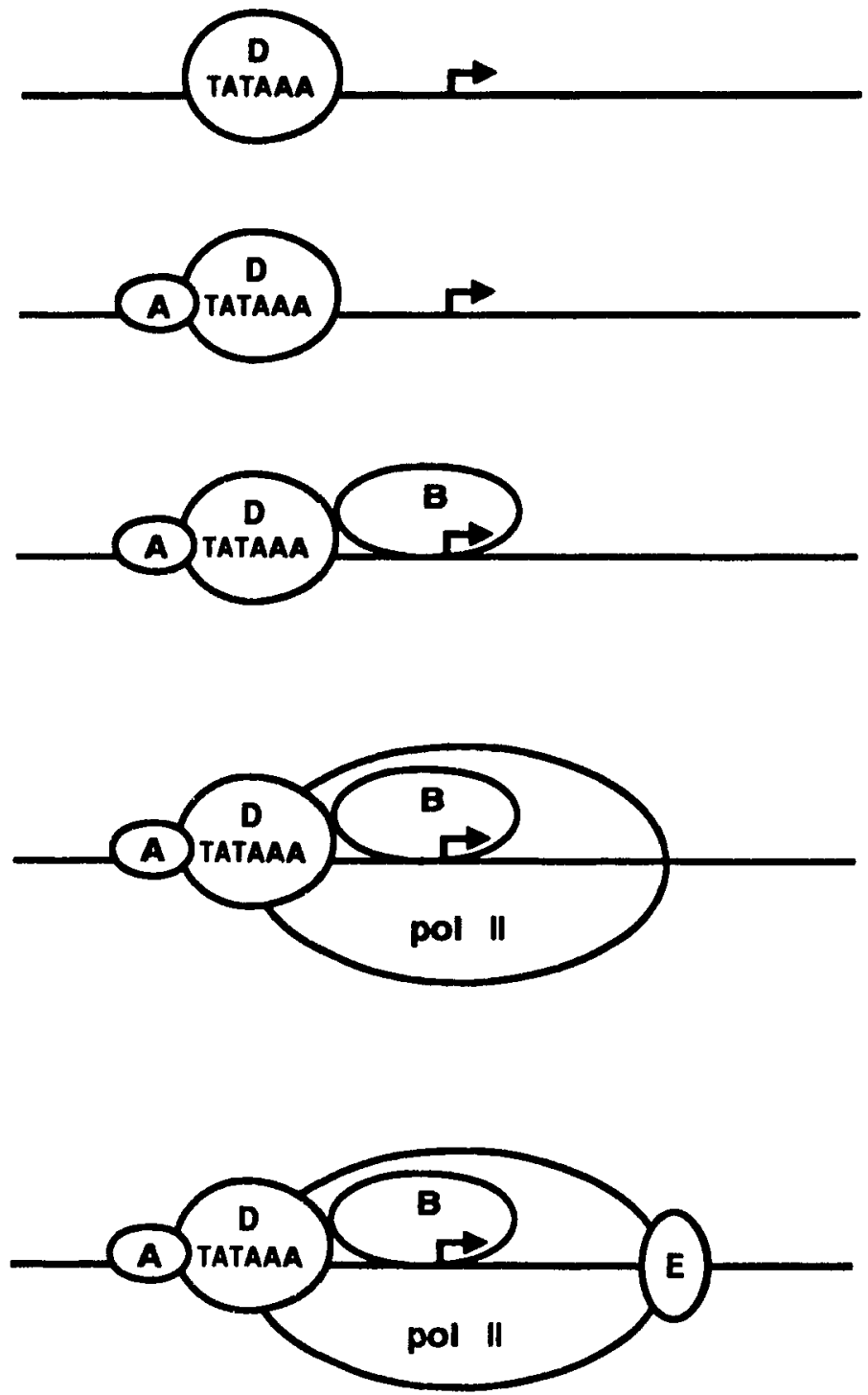
Diagram B. Diagrammatic model of the eloryation steps of eukaryotic protein synthesis. Peptide elongation proceeds in thrce steps. 1. Binding of EF- $1 \alpha$ to GTP and aminoacyl-tRNA leads to the codon-dependent placement of the aminoacyl-tRNA to the A-site on the ribosome. 2. Following release of EF-1 $\alpha$ GDP from the ribosome EF-1B $\gamma$ facilitates the exchange of GTP for the bound GDP. 3. After peptidyl transfer EF-2 translocate the mRNA one codon to allow for arrival of a new aminoacyl t-RNA (after Riis et al., TIBS 15:420-424, Fig. I, 1990). 


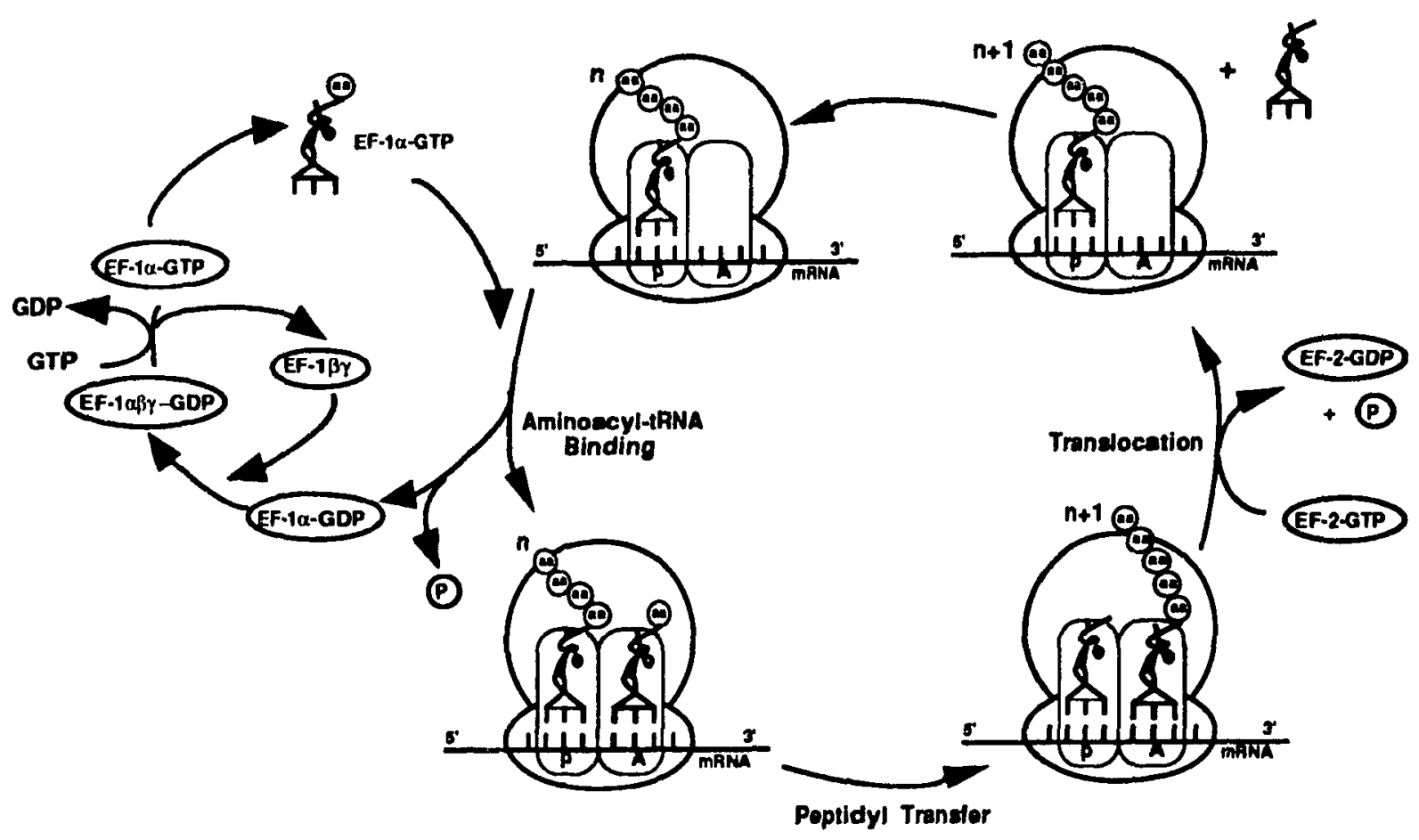


Diagram C. Diagram of the universal M-phase control mechanism. Central to the mechanism is the activation of $\mathrm{p} 34$ protein kinase which induces $\mathrm{M}$-phase. p34 forms a complex with cyclin which activates the p34 for kinase activation. The active form of this protein kinase (PK) phosphorylates key substrates such as $\mathrm{HI}$ histone, lamins, and centrosomal proteins. p80 is required for p34 dephosphorylation and kinase activation. High p34 kinase activity maintains cells in M-phase state, and exit from $M$-phase requires kinase inactivation and phosphatase action. Cyclin, which is degraded as cells exit M-phase, may contribute to the kinase inactivation (modified from Nurse, P., Nature 344:503508, Fig.4, 1990). 





Diagram D. Diagramatic representation of genes controling mitosis in fission yeast. The gene products of $\mathrm{cdc}^{+}$, weel $^{+}$and $\operatorname{nim} \mathrm{l}^{+}$are protein kinases. Overexpression of the activators $\operatorname{cdc} 25^{+}$and nim $1^{+}$, or deletion of the inhibitor wee ${ }^{+}$advances cells into mitosis (modified from Nurse, P., Nature 344:503-508, Fig.2, 1990). 
Network determines mitotic tıming

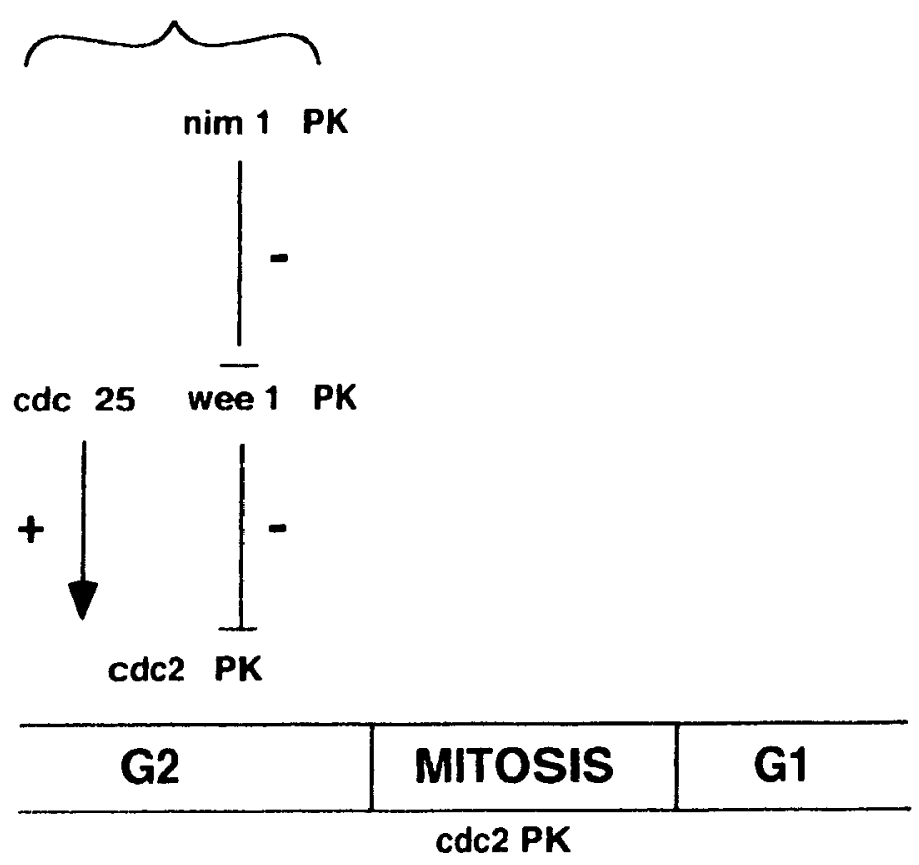


CHAPTER 2 


\section{Introduction}

In an attempt to identify genes involved in controlling cellular growth arrest we previously isolated a cDNA clone, $\mathrm{S1}$, from a rat brain lambda gtl1 cDNA expression library, after immunoscreening with S44 and S30, two monoclonal antibodies to statin. Statin is a nuclear protein found exclusively in non-proliferating cells (Wang, 1985a).

The rat SI cDNA (Wang et al., 1989) and unique rat S1 gene (Ann et al., 1991 a) have been sequenced, and the coding sequences found to be very similar (78\% DNA sequence homology) to those of the human EF-l $\alpha$ gene. The similarity between the deduced amino acid sequence of rat S1 and EF- $1 \alpha$ proteins is even more striking ( $92 \%$ amino acid sequence homology), and indicates that the major functional domains of EF-1 $\alpha$ (e.g. the tRNA- and GTP-binding domains) are also present intact in the $\mathrm{S1}$ protein $(\mathrm{pS} 1)$. Thus we assume that $\mathrm{pSI}$, like EF- $1 \alpha$, probably functions as an elongation factor for protein synthesis together with EF-1B, EF- $1 \gamma$, and EF-1 $\delta$ in the cellular elongation factor complex (Ryanaznov et al.,1991). Whereas mRNA for EF-1 $\alpha$ is found ubiquitously in rat tissues, northern blot analysis showed that the SI mRNA has a tissue-specific distribution (present only in brain, skeletal muscle, and heart) (Lee et al., 1992; Ann et al.. 199/b: Ann et al.. 1992). This is interesting, since it is known that species other than mammals contain more than one EF- $1 \alpha$ gene (e.g. 3 genes in 
frogs and 2 genes in Drosophila and yeast), and that some of the genes are expressed continuously throughout development whereas others are expressed only at particular times during development (e.g. during oogenesis) (Dji et al.. 1990; Kreig et al., 1989; Hovemann et al., 1988). The rat S1 gene and human EF-1 $\alpha$ genes were compared and there is no evident conservation among their intron sequences and first non-translated exon. (Ann et al., 1991a).

Despite the acquisition of molecular data on the rat SI gene and its cDNA. very little is known about the expression and the function of the SI protein. The EF-1 $\alpha$ gene dosage in yeast has been shown to alter translational fidelity (Song et al., 1989). We hypothesized that rat pSI may be required to maintain a high degree of irreversibly growth arrest over long periods of time in differentiated tissues that consist of non-dividing long-lived cells (Lee et al., 1992). In order to test this hypothesis and to study the function of pSI during development (both in vivo and in vitro) one would like to have specific antibodies as a probe for the SI protein. Since $\mathrm{pSI}$ and EF- $\alpha$ have the same molecular mass (49 kDa) and pl (9.8), and very similar amino acid sequences as deduced from the nucleotide sequences it is difficult to distinguish between the SI and EF-I $\alpha$ proteins by physical n.ethods. In this study, I have therefore expressed the SI cDNA in $E$. coli and produced a rabbit antiserum against the recombinant protein. The antiserum raised against $\mathrm{pSI}$ is able to distinguish between $\mathrm{pSI}$ and $\mathrm{EF}-\mathrm{I}$ (x on 
immunoblots and can therefore be used to characterise further the expression and function of $\mathrm{pSI}$ in diverse cell types and tissues.

\section{Materials and Methods}

\section{Plasmid construction and expression of GST-rpS1 fusion protein in $E$. coli}

Full-length rat SI cDNA was first isolated from the pGEM3 transcription vector with $E c o R$ I restriction enzyme at the $E c o R$ I linker site. After that S1 was digested with the restriction enzyme Bal I (BRL) which cleaves at nucleotide 41 of the full length open reading frame. A Bal I - EcoR I (S1) fragment was generated, and then blunt-ended with Klenow (Pharmacia). The plasmid vector pGEX-2T containing the glutathione S-transferase (GST) gene (Pharmacia) was linearized by cutting with restriction enzyme Sma I, and then dephosphorylated with bacterial alkaline phosphatase (Boehringer Mannheim). The SI fragment and the linearized plasmid were ligated together and used to transform competent $\mathrm{HB}$ 101 E. coli (Sambrook et al., 1990; Hanahan, 1983). Recombinant plasmids (pGEX-2T-SI) were selected by resistance to ampicillin, and the S1 insert characterized by restriction enzyme digestion with Sma I and Bam $\mathrm{HI}$ (Pharmacia). Expression from the recombinant plasmids results in a fusion protein that contains, at the N-terminus, the C-terminal domain of GST, which was used to affinity-purify the fusion protein with glutathione-Sepharose 4B (Pharmacia) 
(see below). The GST domain was subsequently removed by digestion with the protease thrombin, which recognizes the LVPRGS motif and cleaves between arginine (R) and glycine (G) (sea below).

\section{Gel purification of the GST-rpS1 fusion protein}

The transformed cultures of $E$. coli were incubated overnight at $37^{\circ} \mathrm{C}$, diluted ten-fold with $2 X Y T$ medium (Difco) containing $50 \mu \mathrm{g} / \mathrm{ml}$ ampicillin, and grown to late log phase $(O D=1.2)$. IPTG (isopropyl-B-D-thiogalactopyronoside) inducer (Boehringer Mannheim) was added to a final concentration of $1 \mathrm{mM}$, and the cultures incubated at $37^{\circ} \mathrm{C}$, usually for 4 hours. The cultures were harvested, washed with PBS, and stored at $-70^{\circ} \mathrm{C}$, or lysed in $50 \mathrm{mM}$ Tris $\mathrm{pH} 7.5$ buffer containing $1 \%$ Triton X-100, $50 \mathrm{mM}$ EDTA, and $1 \mathrm{mM}$ PMSF. The lysed bacteria were sonicated and the inclusion bodies were sedimented by centrifugation at $10,000 \mathrm{~g}$ for 10 minutes at $4^{\circ} \mathrm{C}$. Most (about $80 \%$ ) of the GST-rpSI fusion protein was found in the pelleted fraction containing inclusion bodies. The pellet fraction was solubilized in 2X SDS sample buffer and sonicated for $5 \mathrm{~min}$ at $4^{\circ} \mathrm{C}$. The fraction was analyzed on $9 \%$ SDS-PAGE, and the gels were fixed and stained with Coomassie Blue (Sigma) as described (Lacmmli, 1970). The GST-rpSI fusion protein was excised from the gel, electroeluted at $12 \mathrm{~mA}$ for 5 hours at room temperature in SDS running butfer. The fusion protein was prectpitated with acetone overnight at $4^{\circ} \mathrm{C}$, pelleted and washed twice 
with ice-cold acetone. The vacuum dried fusion protein was then stored at $-20^{\circ} \mathrm{C}$ for further analysis.

\section{Affinity purification of GST-rpS1 fusion protein}

The alternative purification procedure involved glutathione-affinity column chromatography of the recombinant fusion protcin. The supernatant fraction of lysed bacteria (described above), containing approximately $20 \%$ of the GST-S1 fusion proteın, was applied to a $1 \times 10 \mathrm{~cm}$ column of glutathione-Sepharose 4B which was prepared and equilibrated at room temperature with PBS containing $1 \%$ Triton X-100, as described by Smith and Johnson (1988) and according to the manufacturer's (Pharmacia) recommendations. After washing the column with PBS, the bound material was eluted with $50 \mathrm{mM}$ Tris pH 8.0 buffer containing $10 \mathrm{mM}$ glutathione. The GST-S1 fusion protein in the eluted fractions was analysed using 9\% SDS-PAGE, as described above. The fusion protein was lyophilized and keep at $-20^{\circ} \mathrm{C}$ for further analysis.

Production of recombinant S1 protein (rpS1) by cleavage of the GST-rpS1 fusion protein with thrombin

Purified, lyophilized GST-rpS1 fusion protein from both affinity purification and SDS-gel were digested for $40 \mathrm{~min}$ at $25^{\circ} \mathrm{C}$ with $10 \%(\mathrm{w} / \mathrm{w})$ thrombin (Sigma) in a buffer containing $2.5 \mathrm{mM} \mathrm{CaCl}_{2}, 1 \%$ glycerol, $150 \mathrm{mM}$ 
$\mathrm{NaCl}$, and $25 \mathrm{mM}$ Tris $\mathrm{pH} 8.0$, as previously described (Eaton et al., 1986). The reaction was stopped by the addition of SDS to a final concentration of $0.4 \%$ and by heating at $80^{\circ} \mathrm{C}$ for $5 \mathrm{~min}$. The reaction products were separated on $9 \%$ polyacrylamide gels, excised from the gels, electroeluted, and lyophilized as described above.

\section{Production of anti-rpS1 antisera}

Approximately $50 \mu \mathrm{g}$ of purified $\mathrm{rpS1}$ was dissolved in $1 \mathrm{ml}$ of $0.85 \%$ $\mathrm{NaCl}$ or PBS, mixed with an equal volume of Freund's incomplete adjuvant, and used to immunize two rabbits by multiple dorsal intradermal injections. Preimmune and immune antisera were collected and stored at $-20^{\circ} \mathrm{C}$ (Harlow and Lane, 1988). Only one rabbit responded to the immunization.

Fractionation of 3T3 cells into cytoplasmic and nuclear/cytoskeletal proteins Confluent Swiss $3 \mathrm{~T} 3$ cells from five plates were harvested by scraping with a rubber policeman. The cells were collected in PBS and pelleted by low speed centrifugation $(800 \mathrm{~g})$. Cells were resuspended in 10 volumes of a buffer containing $250 \mathrm{mM}$ sucrose, $50 \mathrm{mM}$ triethanolamine $(\mathrm{pH} 7.5), 25 \mathrm{mM} \mathrm{KCl}, 5$ $\mathrm{mM} \mathrm{MgCl}_{2}, 1 \mathrm{mM}$ dithiothreitol, $0.1 \%$ triton $\mathrm{X}-100$ and $2 \mathrm{mM}$ phenylmethylsulfonyl fluoride, and homogenized on ice with approximately 20 strokes in a glass tissue grinder. The homogenate was centrifuged at $4^{\circ} \mathrm{C}$ in a tabletop clinical centrifuge at $800 \mathrm{~g}$ for 15 minutes. The supernatant containing 
the cytoplasmic fraction was frozen for further analysis, and the pellet containing intact nuclei and cytoskeletal components was washed twice by resuspending it in 10 volumes of the same buffer followed by another centrifugation step as above. Proteins in the pelleted nuclear/cytoskeletal fraction were then directly solubilized by sonication for ten minutes in twice the pellet volume of double strength SLI-lysis buffer containing 1.25 M Tris, pH 6.8, 4\% SDS, $10 \%$ Bmercaptoethanol, and 20\% glycerol for SDS-PAGE and western blot analysis.

\section{Immunoblotting}

Immunoblotting was performed essentially as described by Towbin, et al. (1979) except that 0.5\% Tween-20/TBS were used as blocking agents (Batteiger et al., 1982). The rabbit antiserum was used at a dilution of $1: 20$ for 2 hours at room temperature in Tris-buffer containing $0.05 \%$ Tween-20. The bound antibody was delected with horseradish peroxide (HRP) conjugated Goat anti-rabbit IgG (Cappel) and 4-chloro-I-naphthol (Sigma) as substrate.

\section{$\Lambda$ nti-EF-1 $\alpha$ antisera}

Anti-EF- $1 \alpha$ is a rabbit polyclonal antiserum (Ann et al., 1988) raised against a synthetic peptide corresponding to a C-terminal peptide of human EF-1 $\alpha$ (residues 444-462) which is identical to that of mouse EF-1 $\alpha$ and very similar to that of pSI (see Figure 9A). This peptide is not found in bacterial EF-Tu. 


\section{Results}

Expression of recombinant $S 1$ in $E$. coli as a fusion protein

Rat S1 cDNA, slightly shortened at the 5 ' end by 41 base pairs, was cloned into the expression plasmid pGEX-2T, behind the glutathione-S-transferase gene (Figure 3) as described in Methods. For the construction of the recombinant plasmid pGEX-2T-SI, the recombinant SI protein ( $\mathrm{rpSl}$ ) contained a deletion of 11 amino acids at the $\mathrm{N}$-terminus, and a replacement of the subsequent 3 amino acids (GSP replaced VIG) in order to retain the correct reading frame. The remaining amino acid residues (15-463) of $\mathrm{rpSl}$ where otherwise identical to rat S1 (Fig. 6). E. coli HB 101 cells transformed with the recombinant plasmid expressed a fusion protein (GST-rpSI) after induction with IPTG. Al various different time points $(0,0.5,1,2$, or 4 hours $)$ after induction, transformed $E$. coli containing the plasmid vector alone (Fig. 5, panel A) or the recombinant plasmid with the S1 insert (Fig. 5, panel B) were harvested, lysed and bacterial proteins were analysed by SDS-PAGE (Fig. 5). The bacteria transformed only with the expression plasmid pGEX-2T, lacking the SI insert, express a $27 \mathrm{kDa}$ protein (Fig. 5, panel A). This $27 \mathrm{kDa}$ protein corresponding to glutathione-S transferase enzyme increased with time after IPTG induction in bacteria. In contrast, bacteria that were transformed with the recombinant plasmid pGEX-2T-SI produced a 78 $\mathrm{kDa}$ fusion protein that increased in amount between 0 to 4 hours after induction with IPTG (Fig. 5, panel B). In addition to the $78 \mathrm{kDa}$ polypeptide, a $57 \mathrm{kDa}$ 
band was observed in bacteria containing the S1 cDNA also increased in amount after induction (Fig. 5 , panel B). This $57 \mathrm{kDa}$ protein might be a proteolytic cleavage product from the $78 \mathrm{kDa}$ fusion protein.

\section{Purification of the GST-rpS1 fusion protein and proteolytic cleavage}

Purification of the GST-rpS1 protein was performed by glutathione-affinity column chromatography using the soluble fractions of the bacterial lysates (Fig. 6 , lanes A, C) which contained about $20 \%$ of the total fusion protein. This method proved effective, as shown by SDS-PAGE of the eluted fractions (Fig. 6, lanes B, D). The $27 \mathrm{kDa}$ GST was purified from extracts of bacteria that were transformed with plasmid containing the GST gene but not the S1 cDNA (Fig. 6, lanes A, B). When extracts from bacteria that were transformed with plasmid containing both GST and S1 cDNA were used, affinity chromatography resulted a purified $78 \mathrm{k}$ Da fusion protein (Fig. 6, lanes C, D).

Alternatively, the $78 \mathrm{kDa}$ GST-rpS1 fusion protein was excised from gels of bacterial insoluble lysates (Fig. 6, lane E), containing about $80 \%$ of the fusion protein. The GST-rpSI fusion protein was electroeluted and then cleaved with thrombin, to remove the $27 \mathrm{kDa}$ GST domain. Digestion products (Fig. 6, lane G), as well as intact lyophilized fusion protein (Fig. 6, lane F) were then separated on $9 \%$ polyacrylamide gels. The thrombin digestion results in a $50 \mathrm{kDa}$ recombinant $\mathrm{SI}(\mathrm{rpSl})$ and a $27 \mathrm{kDa}$ GST protein in addition to the undigested 
$78 \mathrm{kDa}$ fusion protein (Fig. 6, lane G). After electrophoresis the recombinant pSI was transferred onto PVDF membrane for amino acid sequence analysis, 10 verify that the amino acids were matched to the correct reading frame (data not shown).

\section{Production of a rabbit polyclonal antiserum (anti-rpS1) using recombinant S1 protein as immunogen}

In order to produce an antiserum specific to $\mathrm{rpS} I$, I mixed purified $\mathrm{rpSI}$ with Freund's incomplete adjuvant and immunized two rabbits by multiple dorsal intradermal injections. Only one rabbit responded to the antigen. Rabbit sera obtained were tested for reactivity with $\mathrm{rpSI}$ in solution by immunoprecipilation (data not shown), and on solid phase by immunoblotting using the gel purified 78 $\mathrm{kDa}$ fusion protein before and after thrombin digestion (Fig. 7). Anti-rpSI scrum reacts with the $78 \mathrm{kDa}$ fusion protein and with a $50 \mathrm{kDa} \mathrm{rpSI}$ on immunoblots (Fig. 7, lanes A and B), whereas the 27 kDa GST (see Fig.6, lane G) is not recognized (Fig. 7, lane D). Anti-EF-l $\alpha$ serum (HT7) was tested on immunoblots for reactivity with the GST-rpS1 fusion protein before and after thrombin digestion. The results show that this antiserum does not react with the rpSI fusion protein or the $\mathrm{rpS1}$ itself (Fig. 7, lanes $\mathrm{E}$ and $\mathrm{F}$ ). The preimmune serum (PIS) as a control fails to react with either of the proteins (Fig. 7, lanes C and D).

To determine if anti-rpSI cross reacts with EF- $1 \alpha$, I separated cytoplasmic from nuclear/cytoskeletal fractions of cultured Swiss $3 \mathrm{~T} 3$ cells and analyzed these 
fractions by immunoblotting after SDS-PAGE with either anti-rpS1, preimmune serum, or anti-EF- $1 \alpha$ (Fig. 8). Whereas the HT7 antibody recognizes a $50 \mathrm{kDa}$ band corresponding to EF- $1 \alpha$ exclusively in the cytoplasmic fraction (Fig. 8, lanes $\mathrm{E}$ and F). Anti-rpSI identifies a $80 \mathrm{kDa}$ band in the cytoplasmic fraction (Fig. 8, lane A) and a $100 \mathrm{kDa}$ band in the nuclear/cytoskeletal fraction (Fig. 8, lane B). A faint low molecular weight polypeptide recognized by anti-rpS1 in the nuclear/cytoskeletal fraction of 3T3 cells does also react with the preimmune serum (compare Fig.8, lanes B and D). The results therefore indicate that in $3 \mathrm{~T} 3$ cells rpS1 does not lecognize EF- $1 \alpha$ but at least two other polypeptides of yet unknown identity.

\section{Discussion}

In the present study I have employed the glutathione S-transferase gene (GST) fusion protein system to express a 1.7 kilobase cDNA, S1, in E. coli. The expressed GST-rpSI fusion protein has a molecular weight of $78 \mathrm{kDa}$ on SDS polyacrylamide gels. In vitro proteolytic cleavage with the enzyme thrombin, results in a polypeptide of $50 \mathrm{kDa}$ (the $\mathrm{rpSI}$ protein), and a $27 \mathrm{kDa}$ polypeptide, corresponding to GST itself. I have generated a polyclonal antibody to the recombinant $S I$ protein and shown that on western blots the anti-rpSI serum 
reacts with both the $78 \mathrm{kDa}$ fusion protein and the $50 \mathrm{kDa} \mathrm{rpSl}$, but not with EF-1 $\alpha$ on western blots of proteins obtained from Swiss 3T3 cells. EF-1 $\alpha$ in contrast is recognized on western blots by an antibody against a C-terminal epitope of EF-1 $\alpha$ (HT7) that I used as a control in this study. This antibody. however, does not react with rpSI.

The question arose why anti-rpSI does not recognize EF- $1 \alpha$ and why HT7 does not recognize $\mathrm{rpSl}$, despite the extensive amino sequence homology between the two proteins. The C'-terminal peptide of human liver EF- $1 \alpha$ is conserved in all members of the EF-1 $\alpha$ family. The antibody to EF-l $\alpha$ used in this study is specific to that region (Ann et al., 1988). However, in this region pSI differs from human EF-1 $\alpha$ by three amino acids (Fig. 9). Changes of the amino acid paltern may lead to the failure of the cross reaction between HT7 and anti-rpSI. AntirpS1 and HT7 may recognize this particular pattern.

It is clear that the rat $\mathrm{Sl}$ protein is a member of the eukaryotic EF-Ix family of proteins which are highly conserved during evolution in terms of structure and their essential function in the elongation step of message translation. Elongation factors are among the important cellular proteins found in all living cells. Northern analysis indicated that the amount of SI mRNA in rat brain, heart, and skeletal muscle (Lee et al., 1992) is about 30\% higher than the concentration of EF-1 $\alpha$. We do not know however what the actual amount of the S1 protein is in these tissues relative to that of EF-I $\alpha$. 
An interesting question is why different organisms express multiple EF-1 $\alpha$ genes (e.g. yeast, Drosophila, frogs) and why certain mammalian tissues seem to express more than one gene (e.g. rat brain, heart, and skeletal muscle express S1 in addition to EF-1 $\alpha$ ) while other tissues in the same organism express only one (EF-I $\alpha)($ Ryazanov et al., 1991). The expression of multiple genes may be to produce different FF- $\alpha$ mRNAs with different stabilities for particular developmental stages (Djé et al.,1990). The slightly different EF-1 $\alpha$ proteins in Xenopus have different functional activities as well as different cellular locations (Deschamps et al.,1991), arguing against the idea that multiple EF-1 $\alpha$ proteins are simply a redundant way to achieve particular total levels of EF-1 $\alpha$ protein concentrations during development. Multiple EF- $1 \alpha$ in adults may be involved in the inhibition of the elongation rate and elimination of short lived proteins. Some proteins in the cell that have extremely short half-lives (Bachmair et al., 1986) such as the $\alpha 2$ repressor in yeast has a half-life of about $5 \mathrm{~min}$. (Hochstrasser and Varshavsky, 1990). The steady-state levels of such proteins could be regulated by changes in the overall elongation rate. If cells contain a repressor of transcription or translation having a half life of several minutes, it is very easy to imagine how a transient block of clongation could result in elimination of such a repressor, thereby resultung in an apparent induction of transcription or translation of the gene or mRNA repressed by this short-lived protein. Recent finding reported that cEF- $1<\alpha$ mRA concentration prolong the lifetime in Drosophila (Stepherd et al., 
1989). During ageing of Drosophila, there is a selective decrease in the amount of mRNA for eEF-l $\alpha$. When Drosophila were transformed with a P-element vector containing the eEF- $1 \alpha$ gene, the mean lifetime of transformed flies was 20$40 \%$ longer than the wild type flies. This observation suggested that $\mathrm{eEF}-1 \alpha$ take a role for the regulation of protein synthesis at the elongation stage in the modulation of gene expression.

With a specific antiserum against $\mathrm{pSI}$ on hand we are now able to characterise the expression of S1 in various all types and tissues on the protein level using both immunofluorescence microscopy, as well as immunoblotling techniques. We realize that the high degree of amino acid homology between SI protein and other forms of EF-1 $\alpha$ protein force us to use more specific antibody probes for further detailed molecular studies. The development of specific monoclonal antibodies is under way. 


\section{Figures}


Figure 1. Nucleotide and deduced amino acid sequences of S1 clDNA clone and comparisons with human EF-1 $\alpha$. Dashed lines indiciate identity between the rat $\mathrm{S} 1$ and human EF-l $\alpha(\mathrm{hEF}-1 \alpha)$ sequences. The amuno acid sequence of rat S1 was deduced from the nucleotide sequence of SI cDNA. Gaps are introduced as dota to maximize the alignment. Arrow's indiciate exon/exon junctions. Asterisks represent the different amino acods in EF-I $\alpha$ as a result of different nucleotide sequence between EF- $1 \alpha$ and S!. There are 34 out of 463 amino acids that are different $(92.6 \%$ of the amino acids are common to the two sequences). The translation initiation codon (ATG) and the termination condon (TGA) are boxed. (After Ann et al., J. Biol. Chem. 266:10429-10437, Fig.1, 1991) 

si
net $-1 a$

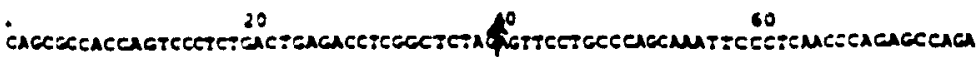

10

\section{0}

$$
120
$$
$m 2 r-1 a$

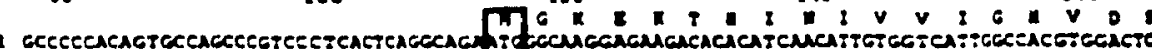

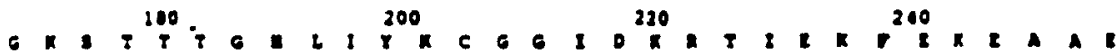

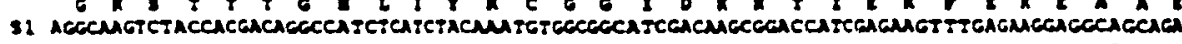

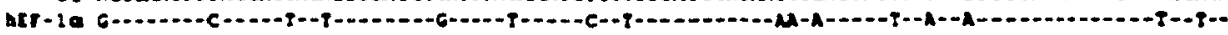

$$
2000300,300,340
$$
ner-10

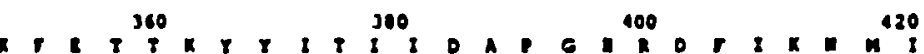

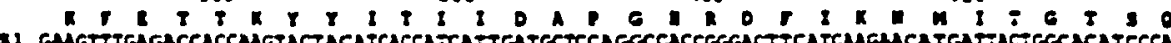

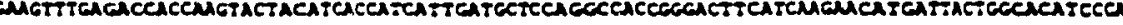

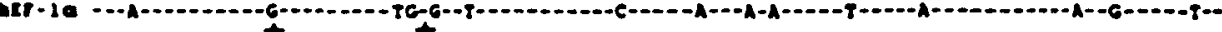
140.160 100 3000

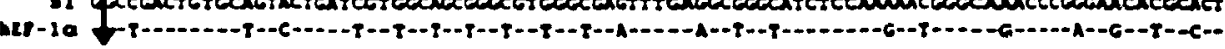

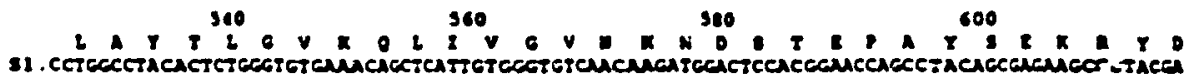

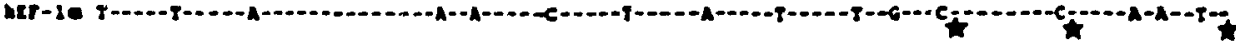

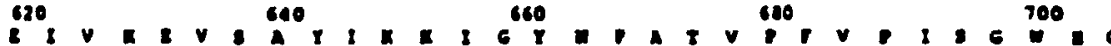

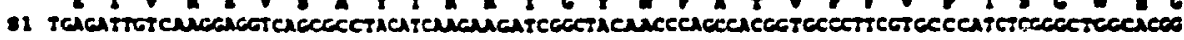

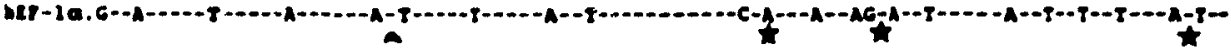

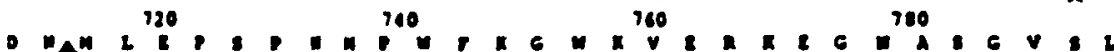

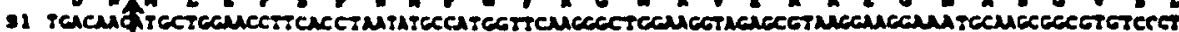

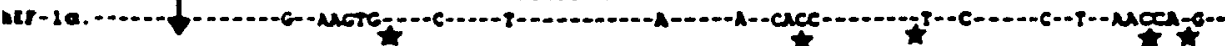

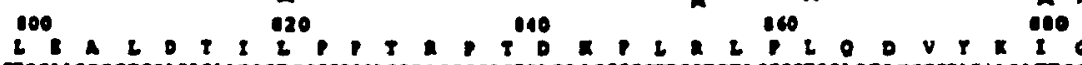

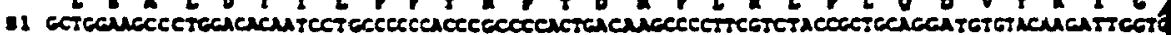

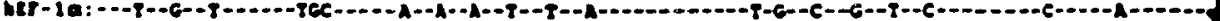

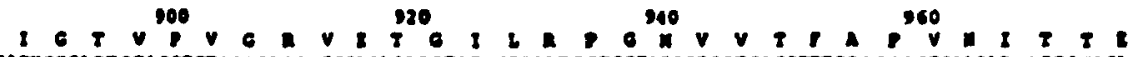

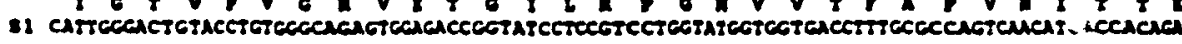

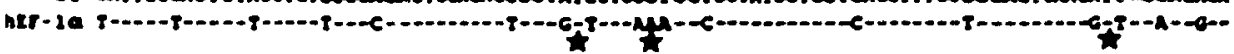

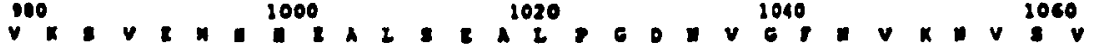

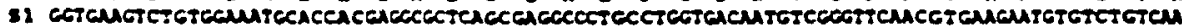

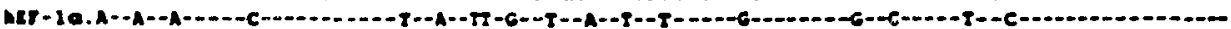

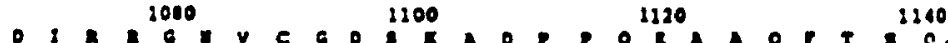

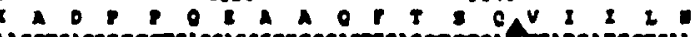

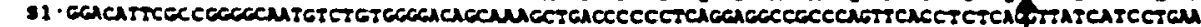
BEr-1a. -.-TG

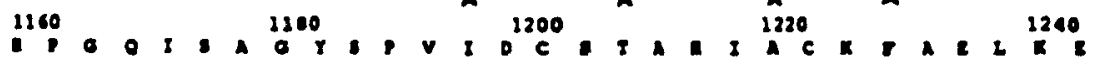

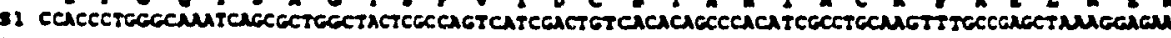

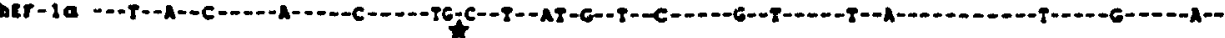

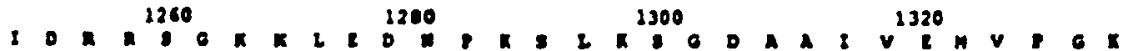

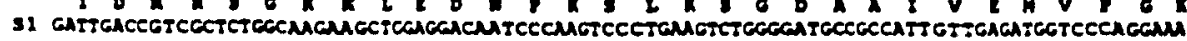

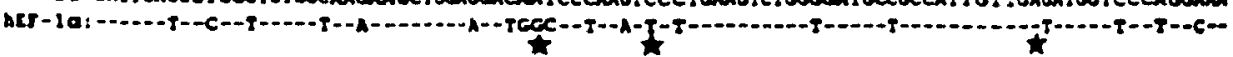

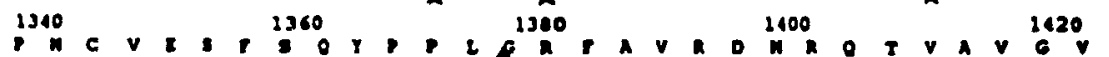

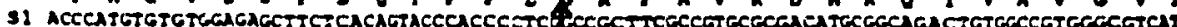

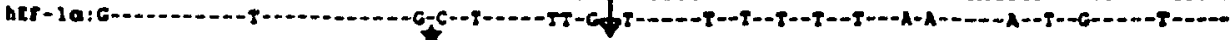

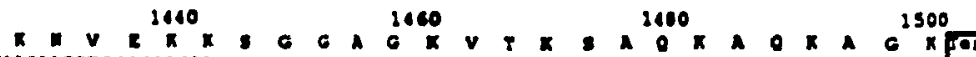

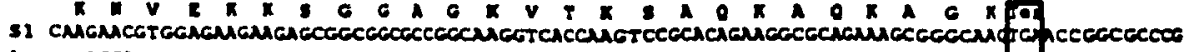

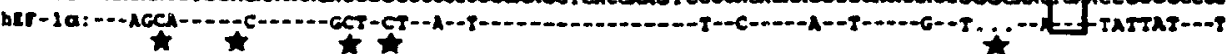

$1520 \quad 1540 \quad 1560 \quad 1310$

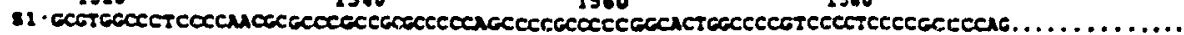

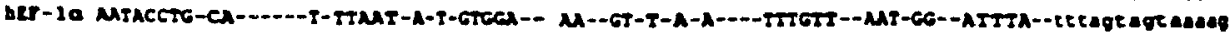

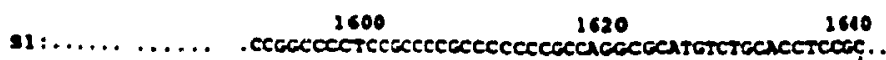

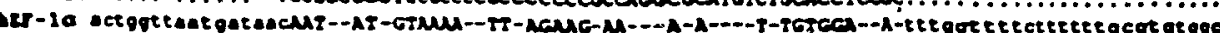

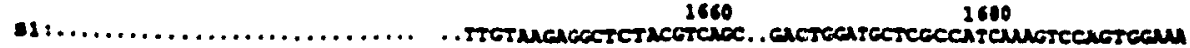

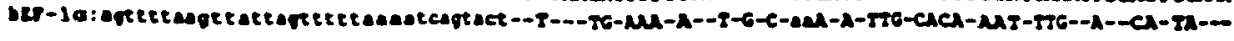

1700

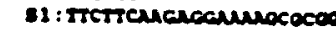

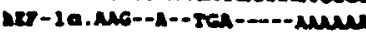




\section{Figure 2. The Glutathione S-transferase (GST) gene fusion system plasmid}

pGEX-2T. The plasmid is constructed to give a fusion protein containing the carboxyl terminus of Schistosoma japonicum glutathione S-transferase protein. The fusion protein can be purified from bacterial lysates by affinity chromatography using glutathione sepharose 4B. The glutathione S-transferase domain was cleaved from the fusion protein by recognituon site for site-specific protease thrombin in the vector immediately upstream from the multiple cloning site. A tac promoter is used to chemically induce high level expression. An internal lacl ${ }^{9}$ gene confers host independence. (modified from Pharmacia, 1990) 
Figure 2

\section{PGEX-2T plasmid}

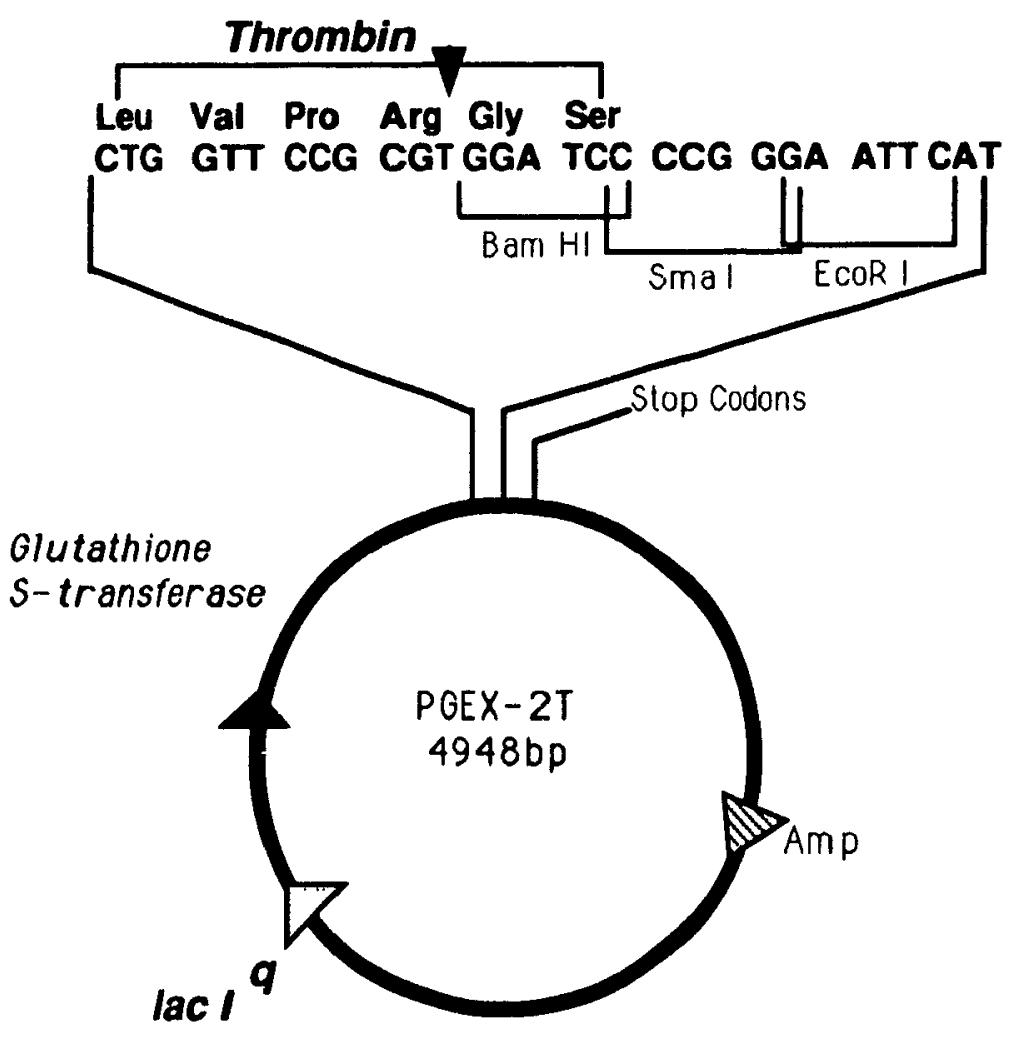


Figure 3A and 3B. Construction of recombinant plasmid pGEX-2T-S1. The details of the construction are given in Methods and are shown schematically here. S1 cDNA (1.6 kb) was cut at nucleotide 41 and 1389 to generate a $B a l l$ EcoR I fragment, the fragment purified, blunt-ended, then ligated into the Sima I site of the plasmid vector pGEX-2T (4948 bp). This resulted in a substitution at position 14 (gly-pro)(Fig. 3A). The recombinant plasmid (6512 bp) was transformed into HB 101 bacteria, and the expressed fusion protein (GST-rpSI) was purified by SDS-PAGE or by affinity chromatography with glutathione-Sepharose 4B, as described in Methods. The purified fusion prolein was digested with the protease thrombin to generale recombinant SI protein ( $\mathrm{rpS} 1$ ), which contained a deletion of the first 11 amino acids, and a substitution of amino acids $12-15$ (GSP-VIG), relative to native $\mathrm{pSI}$ protein. The remaining amino acids were identical in rpS1 and pSI (15-463)(Fig. 3B). 
Figure 3A

pGEX-2T-S1 plasmid

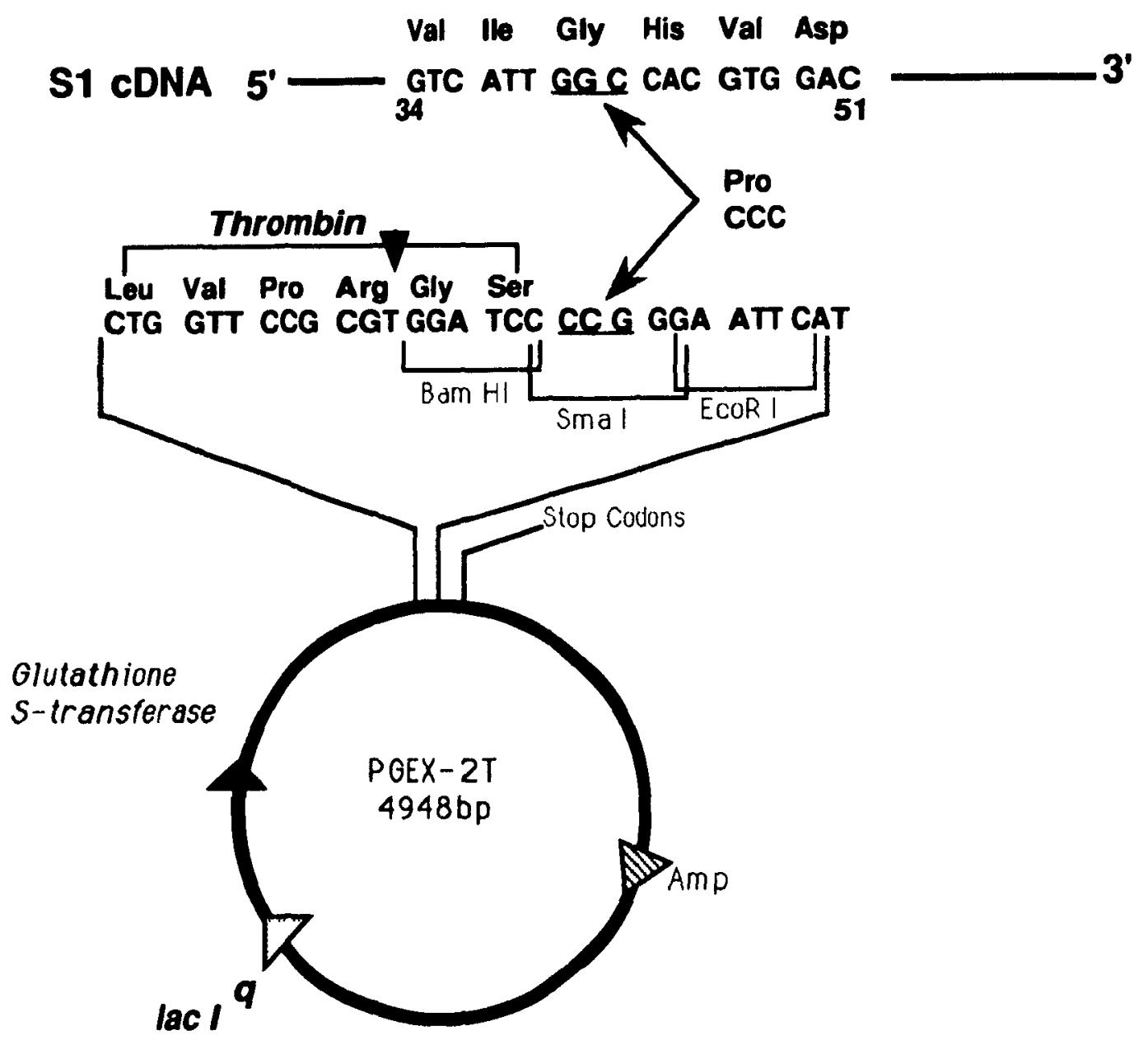


Figure 3B

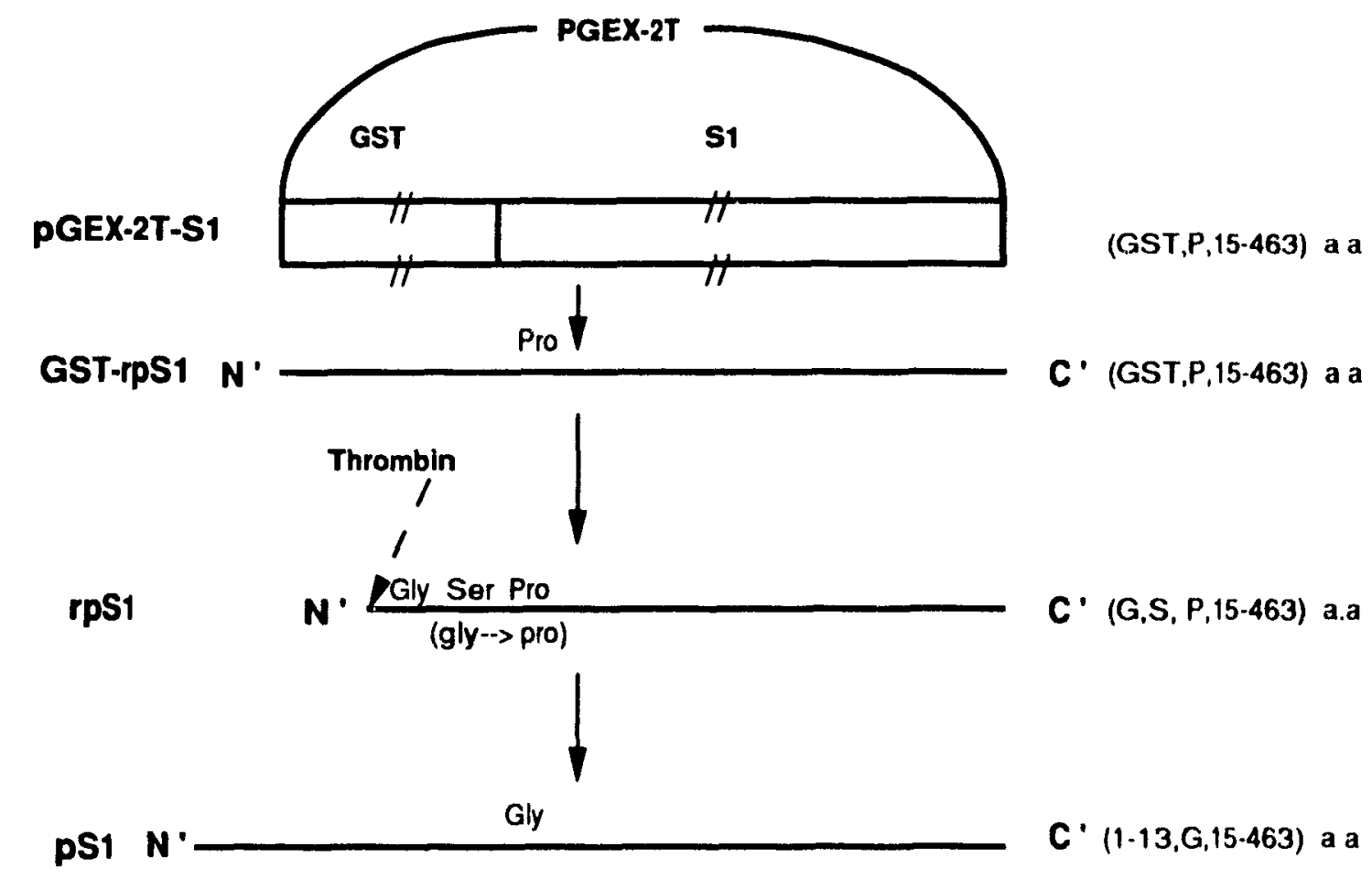


Figure 4. Selection of the recombinant plasmid pGEX-2T-S1. The transformants containıng recombinant plasmid pGEX-2T-SI were selected by ampicillin. Nine individual ampicillin-resistant colonies were picked up and amplified to isolate plasmid DNA for restriction anlysis. Two restriction enzymes Bam HI and Sma I were used for the assay and the digestion products ran on a $1 \%$ agarose gel containing $0.5 \mu \mathrm{l} / \mathrm{ml}$ ethidium bromide. Two recombinant plasmids (lane 2 and 4) cut out a 350 bp fragment (arrow) after restriction encyme digestion to show the correct orientation. The Hind III digested $\lambda$ DNA markers in kilobase (kb) are showed in lane 1 and 11. 


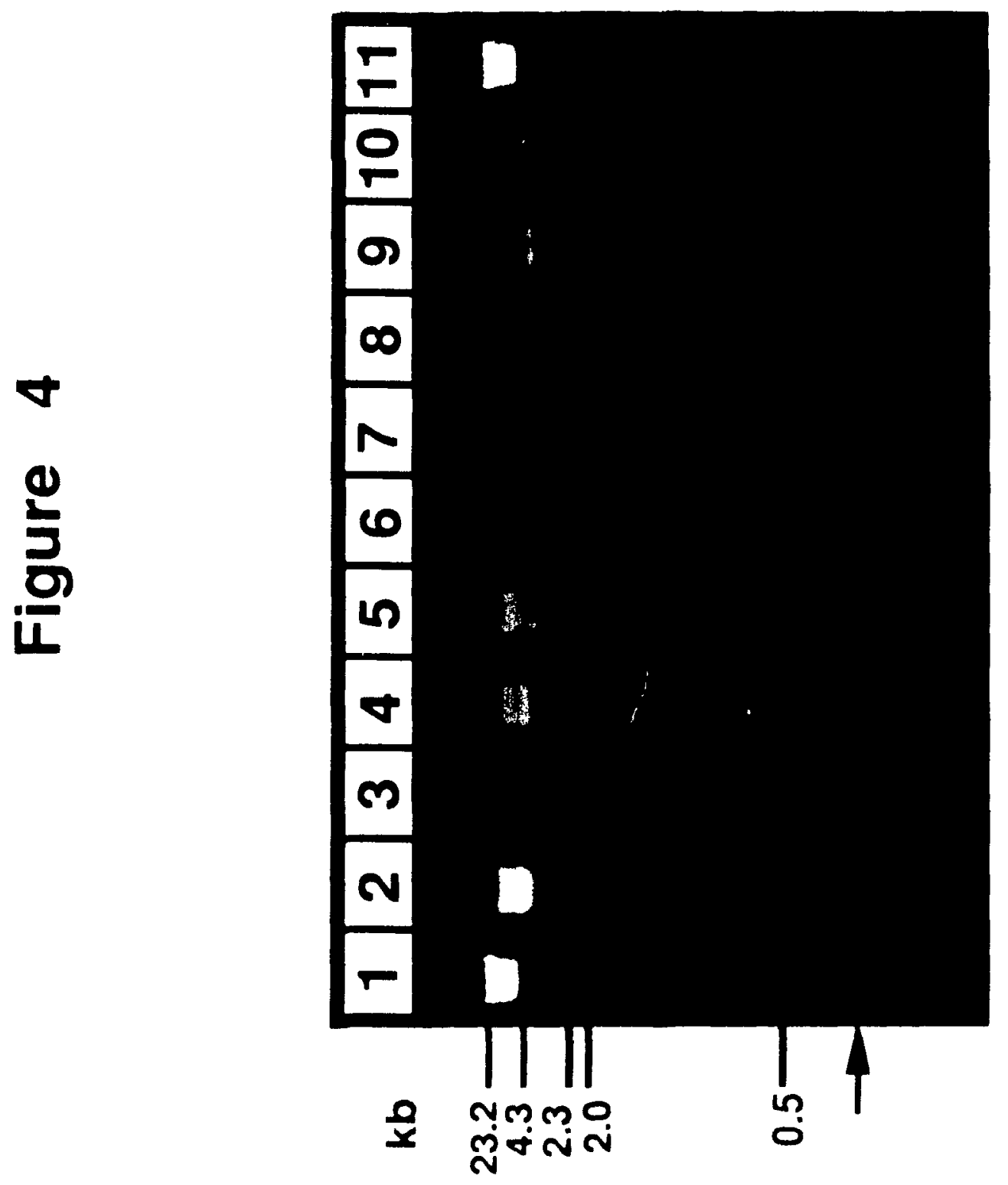

4 
Figure 5. Time course of induction of GST-rpS1 fusion protein synthesis in E. coli. Coomassic blue stained gels of protein extracts of HB101 E. coli transformed with pGEX-2T plasmids containing the S1 sequences, (GST-rpS1), and pGEX-2T plasmids containing only GST. E. coli were harvested and lysed before (0) and $0.5,1,2$, and 4 hours after induction of protein synthesis with IPTG Note that the control bacteria containing only the GST plasmid express a $27 \mathrm{kDa}$ prolem (arrow) that increases $I$ to 4 hours after induction with IPTG. The bacteria transformed with plasmids pGEX-2T-S1, which contain the S1 cDNA, express a $78 \mathrm{kDa}$ fusion protein (arrow) and a protein of about $57 \mathrm{kDa}$ which both increase in amount from 0.5 to 4 hour after induction with IPTG (arrowhead). This $57 \mathrm{kDa}$ polypeptide may be a proteolytic product of the GSTrpSI fusion protein. The positions of prestained molecular weight standard proteins are indicated on the left. 
Figure 5

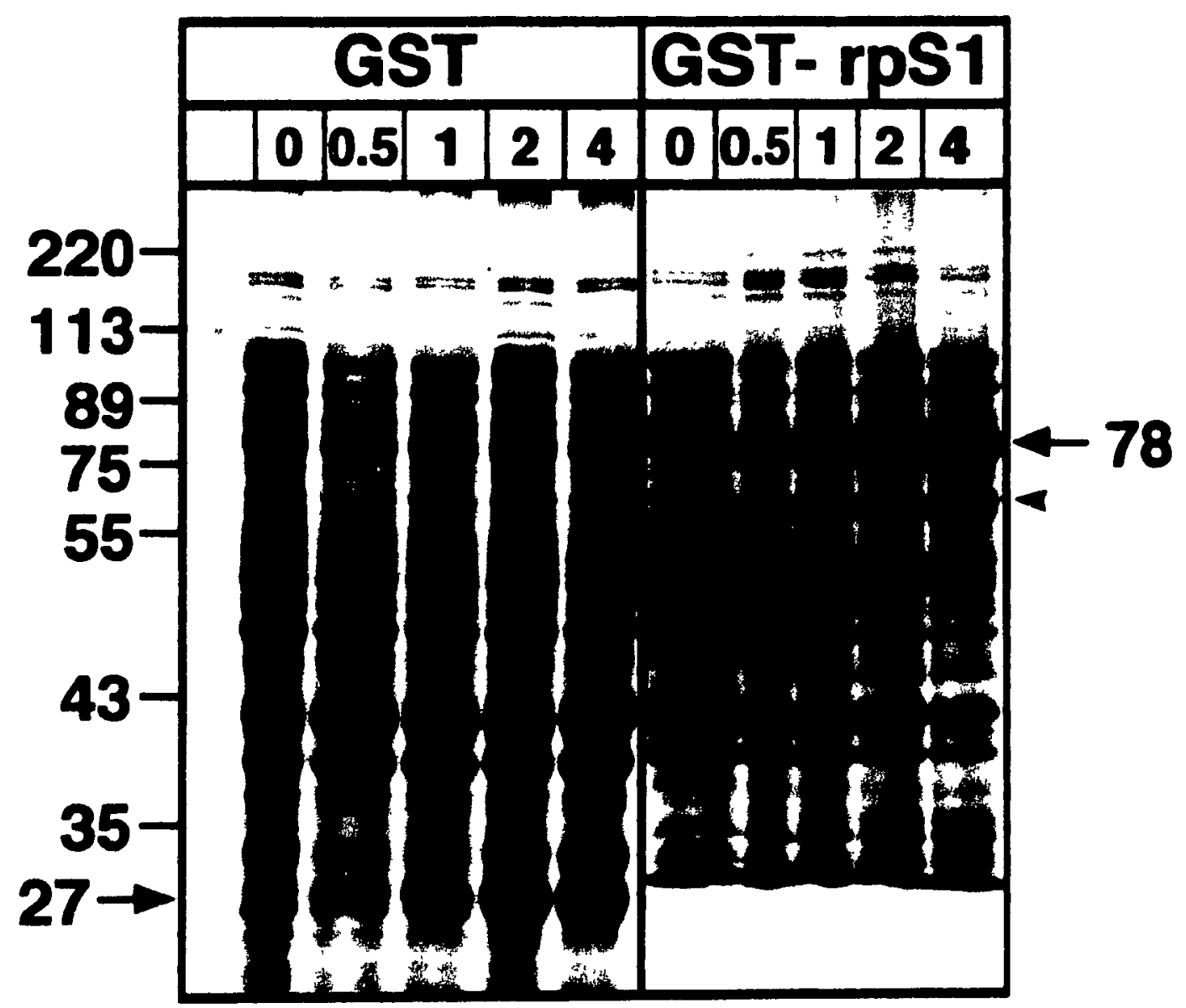


Figure 6. SDS-PAGE analysis of proteins before and after purification. Bacterial extracts were divided into detergent soluble and insoluble fractions. The soluble fraction which contained about $20 \%$ of the induced fusion protein was subjected to affinity chromatography using glutathione sepharose beads. Affinity chromatography of total extracts (TE, lane A) from bacteria transformed with GST containing plasmids resulted in a $27 \mathrm{kDa}$ polypeptide in the eluent (lane B) corresponding to purified GST. While extracts of bacteria transformed with GSTSI containing plasmids were used (TE, lane C), a $78 \mathrm{kDa}$ polypeptide corresponding to the GST-rpSI fusion protein, was obtained in the eluent fraction (lane D). The insoluble fraction, containing $80 \%$ of the induced fusion protein, was used to excise the fusion protein from the gels. The excised GST-rpS1 was then cleaved with thrombin, which resulted in 3 polypeptides corresponding to the $78 \mathrm{kDa}$ uncleaved fusion protein, the $50 \mathrm{kDa} \mathrm{rpSI}$ and the $27 \mathrm{kDa}$ GST (arrow in P(OST, lane G). Note that there is a slight shift in molecular weight of the GST-rpSI before (PRE, lane F) and after cleavage with thrombin (POST, lane G). The relative positions of prestained molecular weight standard proteins are indicated on the left 
Figure 6

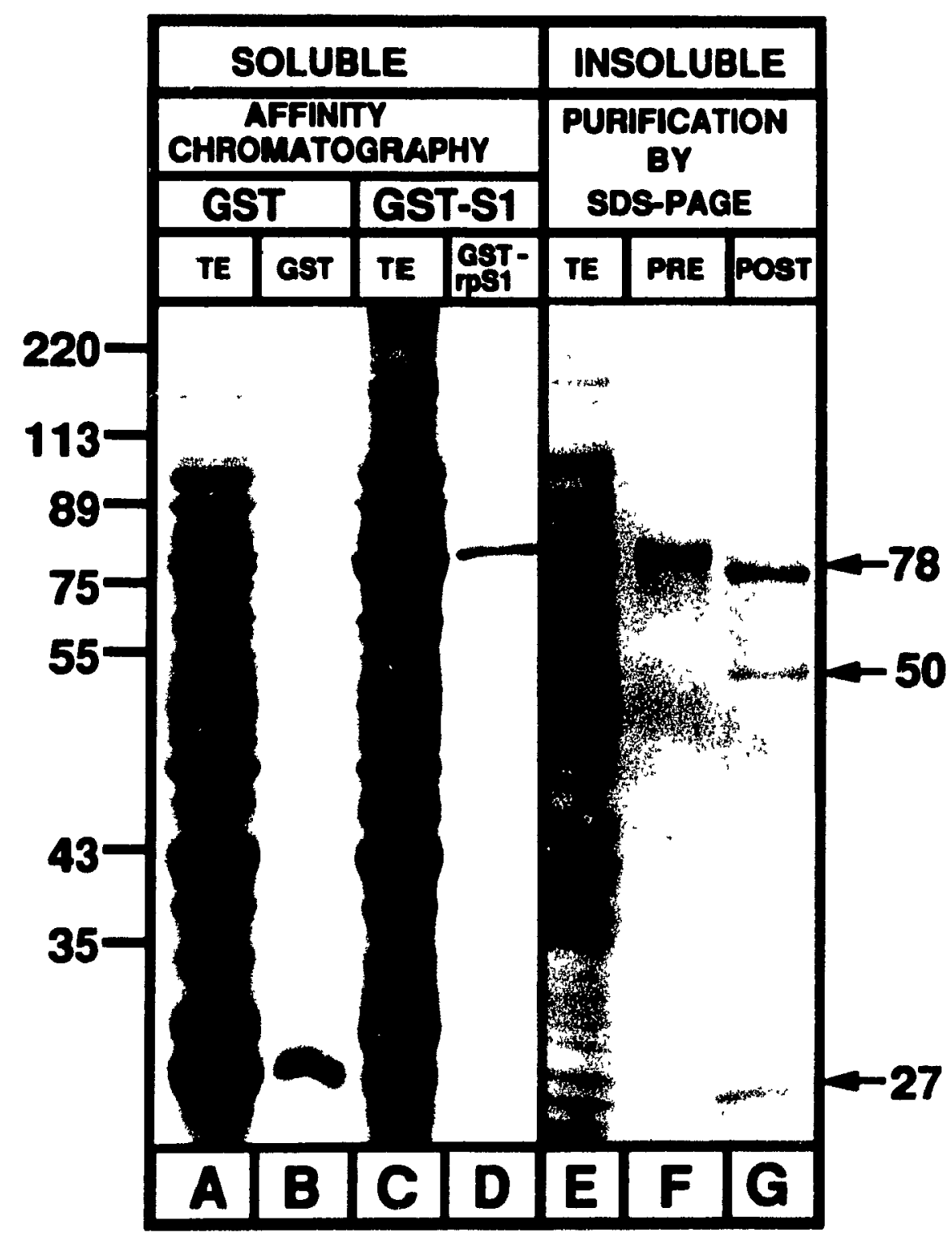


Figure 7. Western blot analysis of gel purified GST-rpS1 fusion protein before (PRE) and after (POST) digestion with thrombin with anti-rpS1 (A, B), preimmune serum (PIS, lanes $C$ and D), and anti-EF-1 $\alpha$ (HT7, lanes E and F). Anti-rpSI recogniass the uncleaved GST-rpSI fusion protein (arrows in lanes $\mathrm{A}$ and $\mathrm{B}$ ) as well as the $50 \mathrm{kDa} \mathrm{rpSl}$ after thrombin digestion (arrowhead in lane B; compare with Fig.3, lanes F and G), but not with the $27 \mathrm{kDa}$ GST (compare with Fig.3, lane G). Some polypeptides below the $78 \mathrm{kDa}$ fusion protein (lane A) and the $50 \mathrm{kDa} r p S I$ (lane B) also react with the anti-rpSl. These are most likely proteolytic breakdown products of GST-rpSI and $\mathrm{rpSl}$ respectively. Nole that nether the preimmune serum nor $\mathrm{HT} 7$ react with GSTrpSI or $\mathrm{rpSI}$. The relative positions of prestaned molecular weight standard proteins are indicaled on the left. 
Figure 7

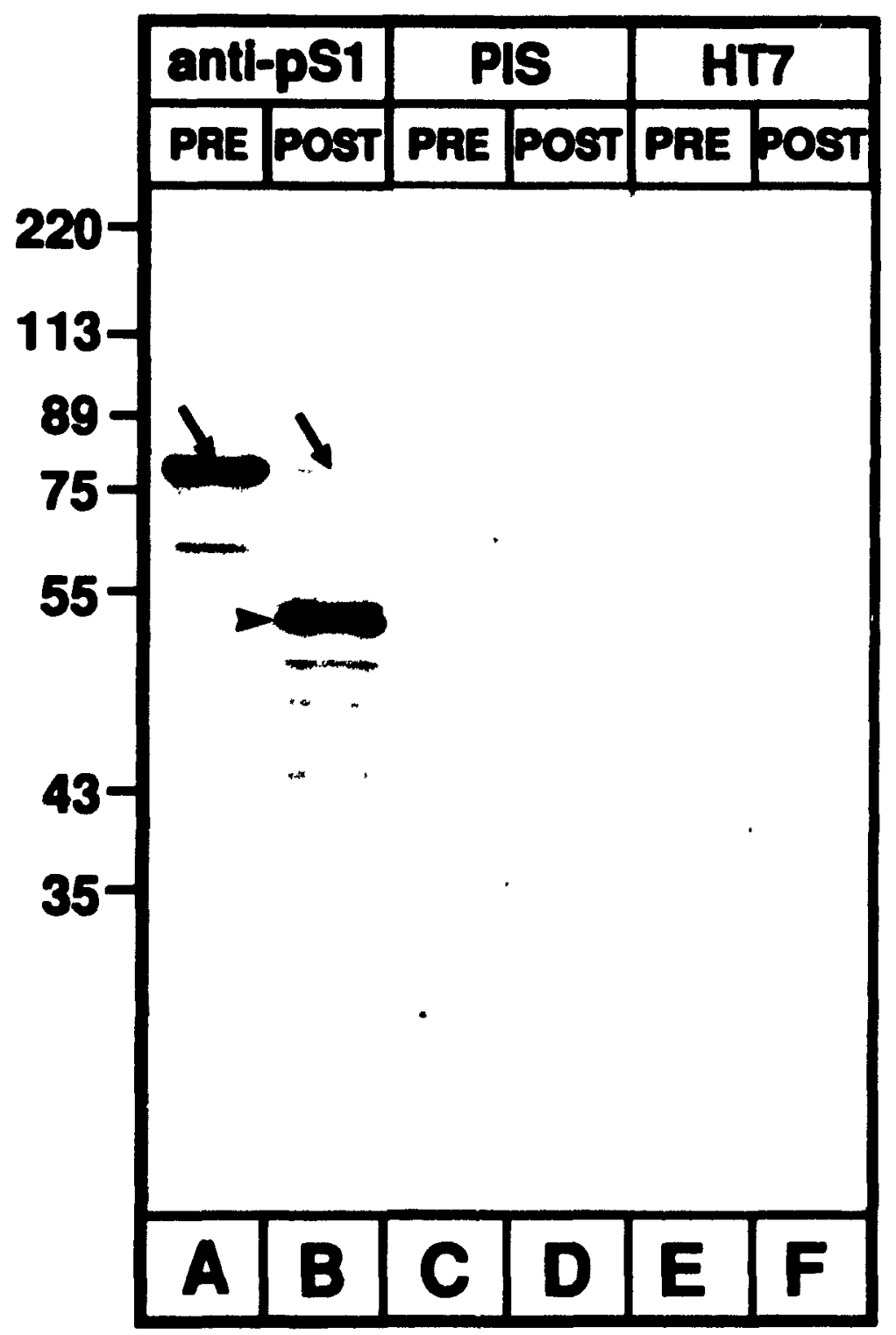

I 
Figure 8. Western blot analysis of cytoplasmic (C) and nuclear/cytoskeletal (N) fractions of 3T3 cells with anti-rpS1 (lanes A and B), preimmune serum (PIS, lanes $(\mathrm{C}$ and $\mathrm{D})$, and anti-EF-1 $\alpha$ (HT7, lanes $\mathrm{E}$ and F). Anti-rpSI reacts with a $80 \mathrm{kDa}$ polypeptide in the cytoplasmic fraction (lane A) and with a 100 kDa and a $37 \mathrm{kDa}$ polypeptide in the nuclear/cytoskeletal fraction (lane B). This $37 \mathrm{kDa}$ band is also faunly seen after reaction with premmune serum (lane D). HT7 recognuses only one $50 \mathrm{kDa}$ polypeptide in the rytoplasmic fraction corresponding to EF-I (lane E). The relative posilions of prestained molecular weight standard proteins are indicated on the left. 
Figure 8

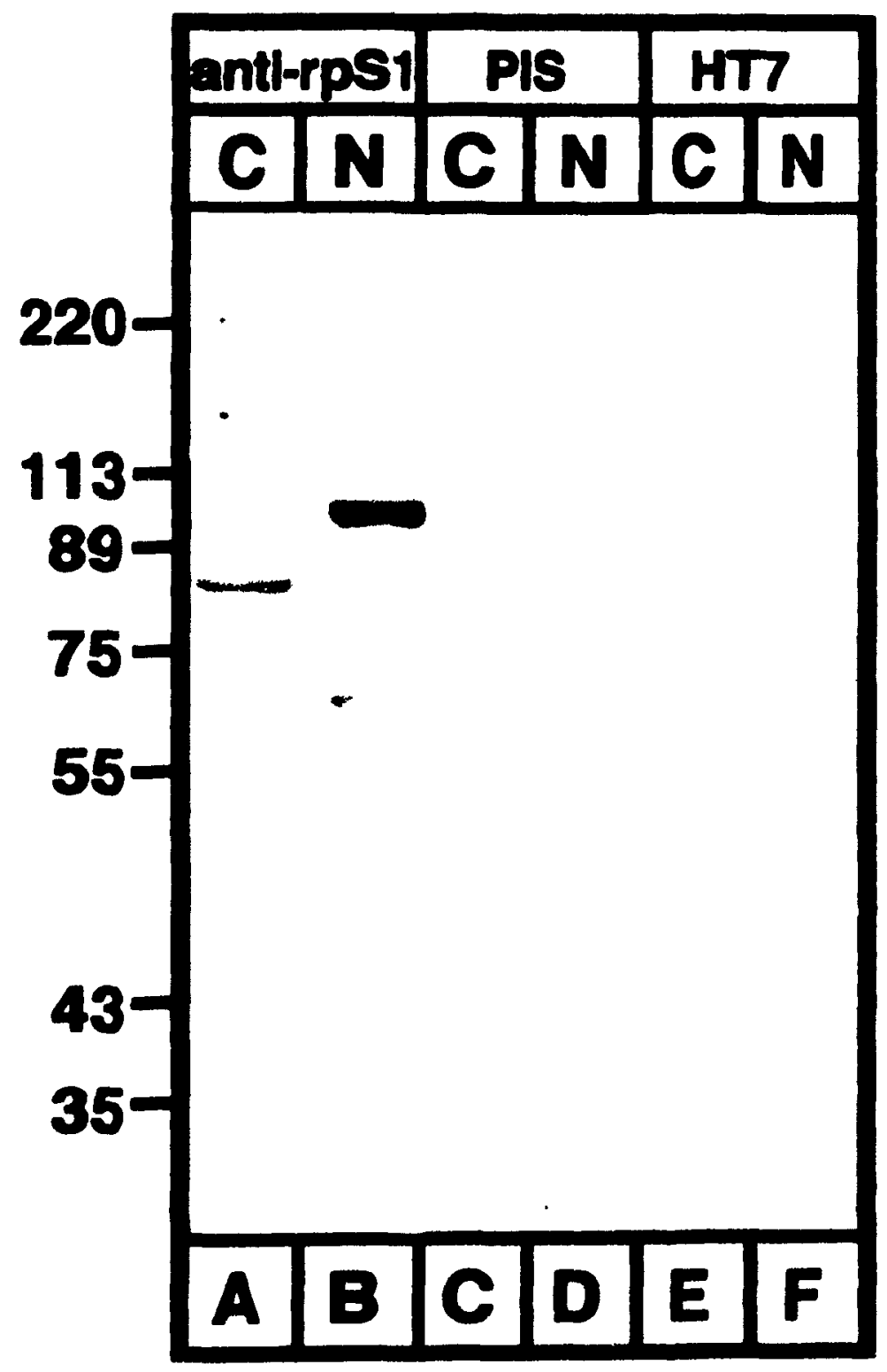


Figure $9 \Lambda$ and $9 B$. Comparison of amino acid sequence of the $C$-terminal peptides of rat brain pS1 and human EF-1 $\alpha$. The C-terminal peptide used to gesurate the anti-EF- $1 \times(\mathrm{HT})$ rabbit antuserum is indicated (box). This sequence 1.s also present in rat brain $p S 1$ and is identical in 17 of the 20 residues, but dilfers in 3 residues (arrows)(Fig 9A). The amino acids from 434-443 (Fig. 9B) all the C-teminal of $p S I$, just beside the region that generate for anti-EF-l $\alpha$ peptude anthbody, there are 2 more residues (arrows) that are different from each other 
Figure 9A

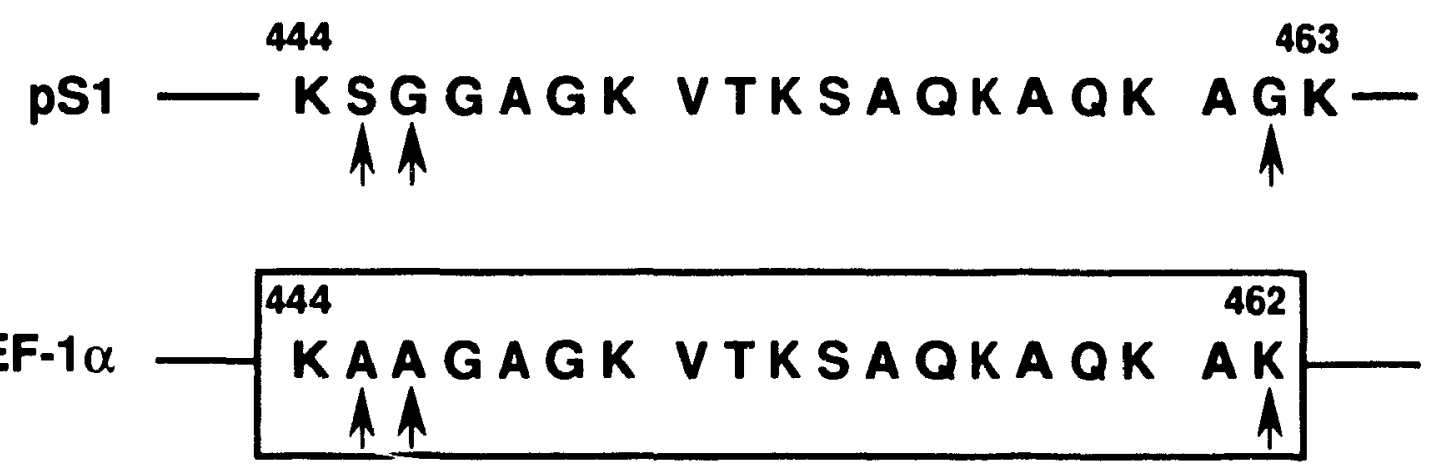

Figure 9B

$$
\text { PS1- AVGVIKN VEKKSG }
$$




\section{CHAPTER 3}

\section{GENERAL DISCUSSION}

As outlined in the literature review, elongation factors are important molecules involved in peptide elongation during message translation in protein synthesis Elongation factors function by mediating aminoacyl-tRNA entry into the ribosomes. GTP molecules bind to the elongation factor-aminoacyl-tRNA complex and are hydrolysed to GDP when the aminoacyl-IRNA has successfully bound to the A-site of the ribosome.

Several types of post-translational modifications of EF- $1 \alpha$, such as methylation (Hiatt et al, 1982; Fronzi et al. 1985; Coppard et al.,1983), phosphorylation (Davydova et al., 1984) and incorporation of ethanolamine (Rosenherry et al, 1989; Whiteheart et al.. 1989), have been observed. For example, EF-la in fungus Mucor racemosus has been previously shown to be post translattonally modified by methylation of lysine residues (Hiatt et al., 1982). Methylation of lysine residues increases the EF-l $\alpha$ activity dramatically while the EF-l $\alpha$ protein and mRNA are made at constant levels (Fronzi et al., 1985). Recenlly it has been shown in cultured somatic cells that methylation of EF- $1 \alpha$ in mouse 3T3B cells is higher than in those transformed with simian-virus SV-40 (Coppard et al., 1983). Whether these modifications play any role in the regulation of EF-l $\alpha$ activity is still unknown. 
Thesaurin-a, a major $48 \mathrm{kDa}$ protein in the previlellogenic oocytes of Xenopus laevis, is part of the $42 \mathrm{~S}$ particles involved in SS RNA and IRNA storage and shows high homology to EF-1 $\alpha$ (Viel et al. 1987). The 42S partick consists of tRNA, 5S RNA and two proteins, thesaurin-a, and the $43 \mathrm{kDa}$ thesaurin-b. Thesaurin-a shares immunological cross-reactivity with EF-lex (Mattaj et al., 1987) and functions similarly to EF-la in transfirring charged amino acids to ribosomes. Thesaurin-a is degraded soon after the imtlatton of vitellogenesis. Its levels decrease from high to undetectable in oocyles during the transition from the previtellogente to the vitellogenic stage. while expression of EF-I $\alpha$ is unchanged. It therefore appears that thesaurin is a stage-specific elongation factor.

In this lab a cDNA clone (S1) has been isolated that showed high homology to human EF-I $\alpha$. In previous studies the SI CDNA was cloned in the Riboprobe vector pGEM-3 blue vector, and a transcription vector, named pG3 S1-7, was constructed. The in vitro transcription and translatuon of $\mathrm{SI}$ (pSI) resulted in a polypeptide of $49 \mathrm{kDa}$. Two dimensional gel electrophoresis indicated that this protein has an isoelectric point of 9.8 . The $3^{\prime}$-untranslated region of SI cDNA (SI-3) and of a EF-1 $\alpha$ cDNA (HT7-3) were used as probes in northern blot analyses 10 detect the mRNA of $\mathrm{Sl}$ and EF- $1 \alpha$ in poly( $\left.\mathrm{A}^{\prime}\right) \mathrm{RNA}$ of mouse 3T3 fibroblasts. S1-3 detected a transcript of $1.8 \mathrm{~kb}$ in size. In 3T3 cells $S 1$ appears to be highly expressed in the $G_{0}$ phase of the cell cycle, but the 
message significantly decreased in cells during $G_{1}$ and $S$ phases. EF- $1 \alpha$, however, detected by HT7-3 at $18 \mathrm{~kb}$, showed a slight decrease in the $G_{1}$ phase and returned to its original level in the $S$ phase. This finding demonstrated that the expression of the EF- I $\alpha$ message is not significantly changed during the transition from $G_{1}$ to $S$ phase

A genomic clone named S10 has been identified by using the S1 cDNA as a probe to screen a rat liver genomic cosmid library (Ann et al., 1991a). Genomic Southern blots indicated that S1 is encoded by a single copy gene in the rat genome and is a unique member of the $\mathrm{EF}-1 \alpha / \mathrm{S} 1$ multigene family. The S10 genomic clone is 12 kılobase pairs in length and contans seven introns. The formatton of exons is virtually identical in Sl compared to human EF- $\alpha$. No TATA box or CAAT box can be found in the proximal 5'-flanking regions from position -1 to -1359 of the rat $S I$ gene. EF- $\alpha$ and $S 1$ share no sequence liomology in the regions of the seven introns, and the two genes differ in length by 5 kilobases.

Studies using immunofluorescence microscopy and S44 anti-statin monoclonal antibody have shown that the expression of statin in cells of the parotid gland significantly decreases when these cells reenter the cell cycle after treatment with isoproterenol, a proliferation-inducing catecholamine. This model system was used to investigate whether terminally differentiated cells of rat parotid glands can also be induced to lose Sl expression as they reenter the cell 
cycle (Ann et al.. 1991b). Using a 5'-SI specific probe. S1-5, northern blot analysis revealed a significant decrease of SI mRNA in isoproterenol treated parotid glands compared to untreated controls.

The expression of $\mathrm{SI}$ and EF- $1 \alpha$ was compared in the parotid and submandibular glands of rats both untreated and treated with isoproterenol To do so and to differentiate $S 1$ from rat EF- $1 \alpha$, a rat EF-I $\alpha \mathrm{CDNA}$ clone was isolated and characterized (Ann et al., 1992). When examined, the rat EF-l $\alpha$ was highly homologous to human and mouse EF-l $\alpha$ in coding and $3^{\prime}$-untranslated regions. However, S1 was highly divergent in its 3'-untranslated region compared to EF$1 \alpha$. Solution hybridization assay was used to compare the mRNA of EF- I $\alpha$ and S1. A prominent reduction of up to $68 \%$ was observed in the SI mRNA of parotid gland cells following isopreterenol treatment A moderate reduction of about $20 \%$ in the message of SI of submandibular gland cells was observed. In contrast, only a slight increase or no changes of EF $I_{\alpha}$ levels in both parotid and submandibular glands following isoproterenol treatment were observed These data suggested that the EF-I $\alpha$ and $S I$ genes are indeed dilferent genes that are differentially expressed and regulated in situ.

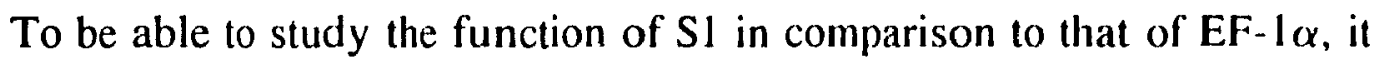
is of importance to have a specific antibody probe to $\mathrm{pSl}$. The expression of cloned genes in Escherichia coli is a good methor to obtain large quantities of protein. These proteins, once purified, can be used to produce antibodies. Some 
prokaryotic expression systems, such as the GST gene fusion system, express the cloned gene in form of a fusion protein coupled in this case to GST. This is of advantage, since now the fusion protein can be separated from bacterial proteins by affinity chromatography using glutathione bound to sepharose beads. In order to separate the expressed protein of interest from the GST, a recognition sequence for a protease, in this case thrombin, is inserted (Nagai and Th $\phi$ geron, 1984), so that the fusion protein can be cleaved with the protease to release the protein of interest

With the GST gene fusion system I have, in this study, successfully expressed a SI CDNA in bacteria and shown that a GST-rpSI fusion protein was produced. In order to provide a tool for both biochemical analysis and cellular characterization of $\mathrm{pSl}$, a polyclonal antiserum against $\mathrm{rpSl}$ was generated.

However, the western blot analyses with anti-rpS1 and $\mathrm{HT} 7$ suggested two alternative possibilities in evaluating whether a specific antibody against $\mathrm{rpS} 1$ has been successfully generated.

1. The western blot analysis of the expressed GST-rpS1 fusion protein before and after thrombin digestion (see Figure 7) suggested that the anti-rpS1 may be indeed a specific antibody which recognizes only rpS1 but not EF-l $\alpha$. Similarly, an antiserum (HT7) against the C-terminal domain (KAAGAGKVTKSAQKAQKAK) of EF-1 $\alpha$ (see Figure 9) does not appear to cross react with $\mathrm{rpS} 1$. This specificity of anti-rpS1 may be explained as follows: 
Two stretches of amino acids in the EF- $1 \alpha$ are involved in the binding of guanine nucleotides (Brands et al., 1986). Region I is centred around position 20 (HINIVVIGHVDSGKSTTTGHL), regıon II around position 154 (IVGVNKMD). The SI cDNA contains the identical regions $I$ and II in comparison to human EF$1 \alpha$. However, due to the construction of new plasmids at region I the amino acids HINIVVI have been cleaved out from the S1 cDNA, and the following glycine has been changed to a non-polar proline. Hence the hydrophilicity of this region I in the SI cDNA is changed. In addition the nucleotide sequence of the SI cDNA clone differs form that of human EF-la at the carboxyl termuni. This results in a difference of three amino acids in the expressed protein in that region (KSGGAGKVTKSAQKAQKAGK)

2. The western blot analysis of $3 \mathrm{~T} 3$ cells showing that anti-rpS1 recognizes a $80 \mathrm{kDa}$ polypeptide in the cytoplasmic fraction and a $100 \mathrm{kDa}$ polypeptude in the nuclear/cytoskeletal fraclion, however, makes an alternative hypollesis possible. These two polypeptides may not be related to pSI, but may be recognized by bacterial protein-specific antibodies that may be present at a high level in the rabbit antiserum. This might be the case, since I did not use the glutathione affinity purified GST-rpS1 to immunize rabbits Instead, for immunization bands were excised from polyacrylamide gels that may have contained bacterial proteins in addition to the $\mathrm{rpSI}$. Therefore, the anti-rpSI antiserum may contain both, antibodies against $\mathrm{rpSl}$ and against some bacterial 
components These bacterial protein-specific antibodies may have reacted strongly with yet unidentified proteins present in $3 \mathrm{~T} 3$ cells. This latter hypothesis appears also possible in light of preliminary immunofluorescence data that indicated a strong nuclear signal of the anti-rpS1 in $3 \mathrm{~T} 3$ cells compared to the preimmune scrum. This observation was surprising since pS1 is most likely a cytoplasmic protein because of its high homology to EF-1 $\alpha$. In order to determine which of the two alternative hypotheses is correct, the anti-rpSI antiserum has to be more carefully characterized in future experiments.

With a specific antibody probe against $\mathrm{rpSl}$ on hand, it is possible to further characterize the expression of S1 in cells and tissues at the protein level. Onc can determine, for example, whether in the cells of the parotid gland the expression of $\mathrm{pS} 1$ is cell cycle related, similar to that of EF- $1 \alpha$, as suggested by earlier studies using cDNA probes. Similarly, serum starvation and stimulation of cells can be used to address this question in cultures. It is also possible now to verify preliminary data using RNase protection assays that indicated a tissue specilic distribution of S1. Both the S1 cDNA and an antibody against pS1 are necessary tools to elucidate the function of S1 and its role in protein synthesis. 


\section{REFERENCES}

Ann, D.K., Wu, M. M. J., Huang, T., Carlson, D. M. and Wu, R. J. (1988). Retinol regulated gene expression in human tracheobronchial epithelial cells: enhanced expression of elongation factor EF- $1 \alpha$. J. Biol. Chem. 263·3546-3549

Ann, D. K., Moutsatsos, I. K., Nakamura, T., Lin, H. H., Mao, P-L., Lec, M-J., Chin, S., Liem, R. K. H., and Wang. E. (1991a). Isolation and characterization of a rat chromosomal gene for a polypeptide $(\mathrm{pS} I)$ antigenically related to statin. J. Biol. Chem. 226:10429-10437

Ann, D. K., Wechsler, A., Lin, H. H., and Wang, E. (1991b). Isoproterenol downregulation of statin-related gene expression in the rat parotid gland J. Cell Sci. 100:641-647

Ann, D.K., Lin, H. H., Lee, S., Tu. Z-J., and Wang, E. (1992). Characterization of the statin-like $S 1$ and rat elongation factor $l \alpha$ as two distinctly expressed messages in rat. J. Biol. Chem. 267:699-702

Arai, K-1., Kawakita, M. and Kaziro, Y. (1972) Studies on polypeptide elongation factors from Escherichia coli. J. Biol. Chem. 247:7029-7037

Bachmair, A., Finley, D. and Varshavsky, A. (1986). In vivo half life of a protein is a function of its amino-terminal residue. Sci. 234:179-186

Baserga, R. (1985) The Biology of Cell Reproduction. Harvard University Press, Cambrigde, M.A. 1985

Batteiger, B., Newhall, W. J., and Jones, R. B. (1982). The use of Tween 20) as a blocking agent in the immunological detection of proteins transferred to nitrocellulose membranes. J. Imm. Meth. 55:297-307

Bauer, G. A. and Burgers, P. M. J. (1988) The yeast analog of mammalian cyclin/proliferating-cell nuclear antigen interacts with mammalian DNA polymerase $\delta$. Proc. Natl. Acad. Sci. USA 85:7506-7510

Benne, R., Edman, J., Traut, R. R. and Hershey, J. W. B. (1978) Phosphorylation of eukaryotic protein synthesis initiation factors. Proc. Natl. Acad. Sci. USA 75:108-112 
Bernstein, P., Peltz, S. W. and Ross, J. (1989) The poly(A)-poly(A)-binding protein complex is a major determinant of mRNA stability in vitro. Mol. Cell. Biol. 9:659-670

Bissonnette, R., Lee, M-J. and Wang, E. (1990) The differentiation process of intestinal epithelial cells is associated with the appearance of statin, a nonproliferation-specific nuclear protein. J. Cell Sci. 95:247-254

Bourgeois, C. A., Raymond, N., Dialıoff-Zito, C. and Macieira-Cochlo, A. (1981) Effect of low dose rate ionizing radiation on the division potential of cells in vitro. VIII. Cytogenic analysis of human fibroblasts. Mech. Aging Dev. $17: 225-235$

Brands, J. H. G. M., Massen, J. A., Van Hemert, F. J., Amons, R. and Möller, W. (1986) The primary structure of the $\alpha$ subunit of human elongation factor 1 . Eur. J. Biochem. 155:167-171

Celis, J. E. and Celis, A. (1985) Cell cycle-dependent variations in the distribution of the nuclear protein cyclin proliferating cell nuclear antigen in cultured cells: subdivision of S phase. Proc. Natl. Acad. Sci. USA 82:3262-3266

Chambon, P. (1975) Eukaryotic nuclear RNA polymerases. Ann. Rev. Biochem. 44:613-638

Chen, P-L., Scully, P., Shew, J-Y., Wang, J. Y. J. and Lee, W-H. (1989) Phosphorylation of the retinoblastoma gene product is modulated during the cell cycle and cellular differentiation. Cell 58:1193-1198

Chodosh, L. A., Baldwin, A. S., Carthew, R. W. and Sharp, P. A. (1988a) Human CCAAT-binding proteins have heterologous subunits. Cell 53:11-24

Chodosh, L. A., Olesen, J., Hahn, S., Baldwin, A. S. Guarente, L. and Sharp, P. A. (1988b) A yeast and a human CCAAT-binding protein have heterologous subunits that are functionally interchangeable. Cell 53:25-35

Circarelli, C., Philipson, L. and Sorrentino, V. (1990) Regulation of expression of growth arrest-specific genes in mouse fibroblasts. Mol. Cell. Biol. 10:15251529

Connolly, J. A., Sarabia, V. E., Kelvin, D. J. and Wang, E. (1988) The disappearance of cyclin-like protein and the appearance of statin art correlated 
with the onset of differentiation during myogenesis in vitro. Exp. Cell Res. $174: 461-471$

Coppard, N. J., Clark, B. F. C. and Cramer, F. (1983) Methylation of elongation factor $1 \alpha$ in mouse 3T3B and 3T3B/SV40 cells. FEBS lett. 164:330334

Corden, J. L., Cadena, D. L., Ahearn Jr., J. M. and Dahmus, M. E. (1985) A unique structure at the carboxyl terminus of the largest subunit of eukaryotic RNA polymerase II. Proc. Natl. Acad. Sci. USA 82:7934-7938

Cristofaio, V. J. and Sharf, B. B. (1973) Cellular senescence and DNA synthesis. Exp. Cell Res. 76:419-427

Curran, T. and Franza Jr., B. R. (1988) Fos and Jun: the AP-1 connection. Cell $55: 395-397$

Dahmus, M.E. (1981) Phosphorylation of Eukaryotic DNA-dependent RNA polymerase. J. Biol. Chem. 256:3332-3339

Dasmahapatra, B. and Chakraburtty, K. (1981) Protein synthesis in yeast. J. Biol. Chem. 256:9999-10004

Davydova, E. K., Sitikov, A. S. and Ovchinnikov, L. P. (1984) Phosphorylation of elongation factor 1 in polyribosome fraction of rabbit reticulocytes. FEBS lett. 176:401-405

De Boer, H. A., Comstock, L.J. and Vasser, M. (1983) The tac promoter: a functional hybrid derived from the $t r p$ and lac promoters. Proc. Natl. Acad. Sci. $80: 21-25$

DeCaprio, J. A., Ludlow, J W., Lynch, D., Furukawa, Y., Griffin, J., PiwnicaWorms, H., Huang, C-M. and Livingston, D. M. (1989) The product of the retinoblastoma susceptibility gene has properties of a cell cycle regulatory element. Cell 58:1085-1095

Desch.mps, S., Morales, J., Mazabraud, A., Le Maire, M., Denis, H., and Brown, D. D. (1991). Two forms of elongation factor $1 \alpha$ (EF-1 $\alpha 0$ and 42Sp50), present in oocytes but absent in somatic cells of Xenopus laevis. J. Cell Biol. 114: $1109-1111$ 
Dholakia, J. N. and Wahba, A. J. (1989) Mechanism of the nucleotide exchange reaction in eukaryotic polypeptide chain iniviation. J. Biol. Chem. 264:546-550

Djé, M. K., Mazabraud, A., Viel, A., Le Maire, M., Dems, H., Crawford, E., and Brown, L. D. (1990). Three genes under different developmental control encode elongation factor 1- $\alpha$ in Xenopus laevis. Nucl. Acids Res. 18:3489-3493

Drescher-Lincoln, C. K. and Smith, J. R. (1984) Inhibition of DNA synthesis in senescent-proliferating human cybrids is mediated by endogenous proteins. Exp. Cell Res. 153:208-217

Duncan, R and Hershey, J. W. B. (1985a) Regulation of initiation factors during translationai repression caused by serum depletion. Abundance, synthesis, and turnover rates. J. Biol. Chem. 260:5486-5492

Duncan, R and Hershey, J. W. B. (1985b) Regulation of initiation factors during translational repression caused by serum depletion. Covalent modification. J. Biol. Chem. 260:5493-5497

Eaton, D., Rodriguez, H., and Vehar, G. A. (1986). Proteolytic Processing of human Factor VIII. Correlation of specific cleavages by thrombin, factor Xa, and activated protein $\mathrm{C}$ with activation and inactivation of factor VIII coagulant activity. Biochem. 25:505-512

Erikson, E. and Maller, J. L. (1986) Purification and characterization of a protein kinase from Xenopus eggs highly specific for ribosomal protein Sf. J. Biol. Chem. 261:350-355

Fabrikant, J. I. (1968) The kinetics of cellular proliferation in regenerating liver. J. Cell. Biol. 36:551-565

Focher, F., Gassmann, M., Hafkemeyer, P., Ferrari, E., Spadari, S. and Hübscher, U. (1989) Calf thymus DNA polymerase $\delta$ independent of proliferating cell nuclear antigen (PCNA). Nucl. Acids Res. 17:1805-1821

Fonzi, W. A., Katayama, C., Leathers, T. and Sypherd, P. S. (1985) Regulation of protein synthesis factor EF-1 $\alpha$ in Mucor racemosus. Mol. Cell. Biol. 5:11(0)1103 
Forsburg S. L. and Guarente, L. (1989) Identification and characterization of HAP4: a third component of the CCAAT-bound HAP2/HAP3 heteromer. Genes Dev. 3:1166-1178

Furano, A. V. (1975) Content of elongation factor Tu in Escherichia coli. Proc. Natl. Acad. Sci. USA 72:4780-4784

Goldstein, S. and Singal, D. P. (1974) Senescence of cultured human fibroblasts: mitotic versus metabolic time. Exp. Cell Res. 88:359-364

Goldstein, S. (1990) Replicative senescence: The human fibroblast comes of age. Science 249:1129-1133

Gould, K. L. and Nurse, P. (1989) Tyrosine phosphorylation of the fission yeast $c d c 2^{+}$prctein kinase regulates entry into mitosis. Nature 342:39-45

Grove, G. L. and Cristofalo, V. J. (1977) Characterization of cell cycle of cultured human diploid cells: Effects of aging and hydrocortisone. J. Cell Physiol. 90:415-422

Guarente, L. and Bermingham-Mcdonogh, O. (1992) Conservation anc' evolution of transcriptional mechanisms in eukaryotes. Trends in Gent. 8:27-32

Hanahan, D.J. (1983). Studies on transformation of $E$. coli with plasmids. Mol. Biol. 166:557-580

Harley, C. B. and Goldstein, S. (1980) Retesting the commitment theory of cellular aging. Science 207:191-193

Harlow, E., and Lane, D. (1988). Antibodies. A laboratory manual. Cold Spring Harbour Laboratory.

Hayflick, L. and Moorhead, P.S. (1961) The serial cultivation of human diploid cell strains. Exp. Cell Res. 25:585-621

Hayflick, L. (1965) The limited in vitro lifetime of human diploid cell strains. Exp. Cell Res. 37:614-636

Hen, R., Sassone-Corsi, P., Corden, J., Gaub, M. P. and Chambon, P. (1982) Sequences upstream from the TATA box are required in vivo and in vitro for 
efficient transcription from the adenovirus serotype 2 major late promoter. Proc. Natl. Acad. Sci. USA 79:7132-7136

Henitz, N., Roeder, R.G. (1982) In Genetic engineering, ed. J.K. Setlow, A. Hollaender, 4:57-89. New York: Plenum

Hershey, J. W. B. (1989) Protein phosphorylation controls translation rates. J. Biol. Chem. 264:20823-20826

Hershey, J. W. B. (1991) Translational control in mammalian cells. Ann. Rev. Biochem. 60:717-755

Herskowitz, I. (1989) $\&$ regulatory hierarchy for cell specialization in yeast. Nature 342:749-757

Hiatt, W. R., Carcia, R., Merrick, W. C. and Sypherd, P. S. (1982) Methylation of elongation factor $1 \alpha$ from fungus Mucor. Proc. Natl. Acad. Sci. 79:3433-3437

Hinnebusch, A. (1984) Evicience for translational regulation of the activator of general amino acid control in yeast. Proc. Natl. Acad. Sci. USA 81:6442-6446

Hochstrasser, M. and Varshavsky, A. (1990) In vivo degradation of a transcriptional regulator: The yeast $\alpha 2$ repressor. Cell 61:697-708

Hooft van Huijsduijnen, R., Li, X. Y., Black, D., Matthes, H., Benoist, C. and Mathis, D. (1990) Co-evolution from yeast to mouse : cDNA cloning of the two NF-Y (CP-1/CBF) subunits. EMBO J. 9:3119-3127

Hovemann, B., Richter, S., Walldorf, U., and Cziepluch, C. (1988). Two genes encode related cytoplasmic elongation factors $1 \alpha$ (EF- $l \alpha$ ) in Drosophila melanogaster with continuous and stage specific expısssion. Nucleic Acids Res. 16:3175-3194

Jackson, R. J. and Standart, N. (1990) Do the poly(A) tail and 3' untranslated region control mRNA translation? Cell 62:15-24

Jaskulski, D., deRiel, J. K., Mercer, W. E., Calabretta, B. and Baserga, R. (1988a) Inhibition of cellular proliferation by antisense oligodeoxynucleotides to PCNA cyclin. Science 240:1544-1546 
Jaskulski, D., Gatti, C. Travali, S. Calabretta, B. and Basgera, R. (1988b) Regulation of the proliferating cell nuclear antigen cyclin and thymidine kinase mRNA levels by growth factors. J. Biol. Chem. 263:10175-10179

Kedinger, C., Gissinger,F. and Chambon, P. (1974) Animal DNA-dependent RNA polymerases. Eur. J. Biochem. 44:421-436

Kozak, M. (1984) Selection of initiation sites by eucaryotic ribosomes: effect of inserting AUG triplets upstream from the coding sequences for preproinsulin. Nucleic Acids Res. 12:3873-3893

Kozma, S. C., Ferrari, S., Bassand, P., Siegmann, M., Totty, N. and Thomas, G. (1990) Cloning of the mitogen-activated S6 kinase from rat liver reveais an enzyme of the second messenger subfamily. Proc. Natl. Acad. Sci. USA 87:7365-7369

Kreig, P. A., Varnum, S. M., Wormington, W. M. and Melton, D. A. (1989). The mRNA encoding elongation factor $1-\alpha(E F-1 \alpha)$ is a major transcript at the midblastula transition in Xenopus. Dev. Biol. 133:93-100

Lacmmli, U. K. (1970). Cleavage of structural proteins during the assembly of the head of bacteriophage T4. Nature (London) 227:680-685

Laybourn, P. J. and Dahmus, M. E. (1989) Transcription-dependent structural changes in the C-terminal domain of mammalian RNA polymerase subunit IIa/o. J. Biol. Chem. 264:6693-6698

Lee, S., Francoeur, A. M., and Wang, E. (1992). Tissue-specific expression of Statin-like SI, a gene highly homologous to EF-1 $\alpha$. (in preparation)

Lewin, B. (1990) Commitment and activation at pol Il promoters: a tail of protein-protein interactions. Cell 61:1161-1164

Lohka, M. J., Hayes, M. K. and Maller, J. L. (1988) Purification of maturationpromoting factor, an intracellular regulation of early mitotic events. Proc. Natl. Acad. Sci. USA 85:3009-3013

Lohka, M. J. (1989) Mitotic control by metaphase-promoting factor and $c d c$ proteins. J. Cell Sci. 92:131-135 
Lumpkin Jr.,C. K., McClung, K., Pereira-Smith, O. M. and Smith, J. R. (1986) Existence of high abundance antiproliferative mRNA's in senescent human diploid fibroblasts. Science 232:393-395

Manfioletti, G., Ruaro, M. E., Del Sal, G., Philipson, L. and Schneider, C. (1990) A growth arrest-specific (gas) gene codes for a membrane protein. Mol. Cell. Biol. 10:2924-2930

Maity, S. N., Vuorio, T. and de Crombrugghe, B. (1990) The B subunit of a rat heteromeric CCAAT-binding transcription factor shows a striking sequence identity with the yeast Hap2 transcription factor. Proc. Natl. Acad. Sci. USA 87:5378-5382

Maniatis, T., Goodbourn, S. and Fischer, J.A. (1987) Regulation of inducible and tissue-specific gene expression. Science 236:1237-1244

Martin, G. M., Sprague, C. A., Epstein, C. J. (1970) Replicative lifespan of cultivated human cells - Effects of donor age, tissue and genotype. Lab. Invest. 23:86-92

Mathews, M. B., Bernstein, R. M., Franza, B. R. and Garrels, J. I. (1984) Identity of the proliferating cell nuclear antigen and cyclin. Nature 309:374-376

Matsumura, T., Pfendt, E. A., Zerrudo, Z. and Hayflick, L. (1980) Senescent human diploid cells (WI-38). Exp. Cell Res. 125:453-457

Mattaj, I. W., Coppard, N. J., Brown, R. S., Clark, B. F. C. and De Roberts, E. M. (1987) $42 S$ p 48 - the most abundant protein in previtellogenic Xenopus oocytes - resembles elongation factor $1 \alpha$ structurally and functionally. EMBO J. $6: 2409-2413$

Mitchell, P. J. and Tjian, R. (1989) Transcriptional regulation in mammalian cells by sequence-specific DNA binding proteins. Science 245:371-378

Moldave, K. (1985) Eukaryotic protein synthesis. Ann. Rev. Biochem. 54:11091149

Morley, S. and Traugh, J. A. (1990) Differential stimulation of phosphorylation of initiation factors eIF-4F, eIF-4B, eIF-3, and ribosomal protein S6 by insulin and phorbol esters. J. Biol. Chem. 265:10611-10616 
Müller, R., Bravo, R., Burckhardt, J., and Curran, T. (1984) Induction of c-fos gene and protein by growth factors precedes activation of c-myc. Nature 312:716720

Murray, A. W. (1988) A mitotic inducer matures. Nature 335:207-208

Murray, A. W. (1989) The cell cycle as a $c d c 2$ cycle. Nature 342:14-15

Nagai, K and Thфgersen, H. C. (1984) Generation of B-globin by sequencespecific proteolysis of a hybrid protein produced in Escherichia coli. Nature 309:810-812

Norman, C., Runswick, M., Pollock, R. and Treisman, R. (1988) Isolation and properties of cDNA clones encoding SRF, a transcription factor that binds to the c-fos serum response element. Cell 55:989-1003

Norwood, T. H., Pendergrass, W. R., Sprague, C. A. and Martin, G. M. (1974) Dominance of the senescent phenotype in heterokaryons between replicative and post-replicative human fibroblast-like cells. Proc. Natl. Acad. Sci. USA 71:2231223.5

Norwood, T. H., Pendergrass, W. R. and Martin, G. M. (1975) Reinitiation of DNA synthesis in senescent human fibroblasts upon fusion with cells of unlimited growth potential. J. Cell Biol. 64:551-556

Nurse, P. (1990) Universal control mechanism regulating onset of M-phase. Nature 344:503-508

Ovchinnikov, L. P., Motuz, L. P., Natapov, P. G., Averbuch, L. J., Wettenhall, R. E. H., Szyszka, R.,Kramer, G. and Hardesty, B. (1990) Three phosphorylation sites in elongation factor 2. FEBS lett. 275:209-212

Owen, T. A., Soprano, D. R. and Soprano, K. J. (1989) Analysis of the growth factor requirements for stimulation of WI-38 cells after extended periods of density-dependent growth arrest. J. Cell. Physiol. 139:424-431

Owen, T. A., Carter, R., Whitman, M. M, Soprano, D. R. and Soprano, K. J. (1990) Evidence that density-dependent growth arrest is a two-stage process in W'l-38 cells. J. Cell. Physiol. 142:137-148 
Pardee, A. B. (1989) $G_{1}$ events and regulation of cell proliferation. Science 246:603-608

Pereira-Snith, O. M. and Smith, J. R. (1988) Genetic analysis of indeline division in human cells: Identification of four complementation groups. Proc. Natl. Acad. Sci. USA 85:6042-6046

Peterson, M. G., Tanese, N., Pugh, B. F., Tjian, R. (1990) Functional domains and upstream activation properties of cloned human TATA binding protein. Science 248:1625-1630

Pugh, B. F. and Tjian, R. (1990) Mechanism of transcriptional activation by Spl: evidence for coactivators. Cell 6i:1187-1197

Riis, B., Rattan, S. I. S., Clark, B. F. C. and Merrick, W. C. (1990) Eukaryotic protein elongation factors. TIBS 15:420-424

Rittling, S. R., Brooks, K. M., Cristofalo, V. J. and Baserga, R. (1986) Expression of cell cycle-dependent genes in young and senescent WI-38 fibroblasts. Proc. Natl. Acad. Sci. USA 83:3316-3320

Rosenberry, T. L., Krall, J. A., Dever, T. E., Haas, R., Louvard, D. and Merrick, W. C. (1989) Biosynthetic Incorporation of '|H|ethanolamine into protein synthesis elongation factor $1 \alpha$ reveals a new post-Iranslational protein modification. J. Biol. Chem. 264:7096-7099

Russell, P. and Nurse, P. (1986) $c d c 25^{+}$functions as an inducer in the mitotic control of fission yeast. Cell 45:145-153

Russell, P. and Nurse, P. (1987a) Negative regulation of mitosis by weel ${ }^{\dagger}$, a gene encoding a protein kinase homolog. Cell 49:559-567

Russell, P. and Nurse, P. (1987b) The mitotic inducer mim functions in a regulatory network of protein kinase homologs controlling the initiation of mitosis. Cell 49:569-576

Ryazanov, A. G. and Davydova, E. K. (1989) Mechanism of elongation factor 2 (EF-2) inactivation upon phosphorylation. FEBS lett. 251:187-190 
Ryazanov, A. G., Rudkin, B. B., and Spirin, A. S. (1991). Regulation of protein synthesis at the elongation stage. New insights into the control of gene expression in eukaryotes. FEBS Lett. 285:170-175

Sadaie, M. R. and Mathews, M. B. (1986) Immunochemical and biochemical analysis of the proliferating cell nuclear antigen (PCNA) in Hela cells. Exp. Cell Res. 163:423-433

Safer, B. (1989) Nomenclature of initiation, elongation and termination factors for translation in eukaryotes. Eur. J. Biochem. 186:1-3

Saha, S. K. and Chakraburtty, K. (1986) Protein synthesis in yeast. J. Biol. Chem. 261:12599-12603

Sambrook, J., Fritsch, E. F., and Maniatis, T. (1990). Molecular Cloning: A laboratory manual. Cold Spring Harbour Laboratory.

Schipper, H. M. and Wang, E. (1990) Expression of statin, a nonproliferationdependent nuclear protein, in the postnatal rat brain: evidence for substantial retention of neuroglial proliferative capacity with aging. Brain Res. 528:250-258

Schneider, C., King, R. M. and Philipson, L. (1988) Genes specifically expressed at growth arrest of mammalian cells. Cell 54:787-793

Sentenac, A. (1985) Eukaryotic RNA polymerases. CRC Crit. Rev. Biochem. $18: 31-90$

Seshadri. T. and Campisi, J. (1990) Repression of c-fos transcription and an altered genetic program in senescent human diploid fibroblasts. Science 247:205209

Sester, U., Moutsatsos, I. K. and Wang, E. (1989) A rat liver $57 \mathrm{kD}$ protein is identified to share antigenic determinants with statir, a marker for nonprolifcrating cells. Exp. Cell. Res. 182:550-558

Shepherd, J. C. W., Walldorf, U., Hug, P. and Gehring, W. J. (1989) Fruit flies with additional expression of elongation EF- $1 \alpha$ live longer. Proc. Natl. Acad. Sci. USA 86:7520-752! 
Sherwood, S. W., Rush, D., Ellsworth, J. L. and Schimke, R. T. (1988) Defining cellular senescence in IMR-90 cells: a flow cytometric analysis. Proc. Natl. Acad. Sci. USA 85:9086-9090

Simanis, V. and Nurse, P. (1986) The cell cycle control gene $c d c 2^{+}$of fission yeast encodes a protein hinase potentially regulated by phosphorylation. Cell $45: 261-268$

Slobin, L. I. (1980) The role of eucaryotic elongation factor Tu in protein synthesis. Eur. J. Biochem. 110:555-563

Smale, S. T. and Baltimore, D. (1989) The "initiator" as a transcription control element. Cell 57:103-113

Smith, D. B., and Johnson, K. S. (1988). Single step purification of polypeptides expressed in Escherichia coli as fusions with glutathione S-transferase. Gene $67: 31-40$

Song, J. M., Picologlou, S., Grant, C. M., Firoozan, M., Tuite, M. F., and Liebman, S. (1989). Elongation factor EF- $1 \alpha$ gene dosage alters translational fidelity in Saccharomyces cerevisiae. Mol. Cell. Biol. 9:4571-4575

Stein, G. H. and Yanishevsky, R. M. (1979) Entry into S phase is inhibited in two immortal cell lines fused to senescent human diploid cells. Exp. Cell Res. 120:155-165

Stein, G. H. and Yanishevsky, R. M. (1981) Quiescent human diploid cells can inhibit entry into $S$ phase in replicative nuclei in heterodikaryons. Proc. Nall. Acad. Sci. USA 78:3025-3029

Stein, G. H., Yanishevsky, R. M., Gordon, L. and Beeson, M. (1982) Carcinogen-transformed himan cells are inhibited from entry into $S$ phase by fusion to senescent cells but cells transformed by DNA tumor viruses overcome the inhibition. Proc. Natl. Acad. Sci. USA 79:5287-5291

Stein, G. H., Beeson, M. and Gordon, L. (1990) Failure to phosphorylate the retinoblastoma gene product in senescent human fibroblasts. Science 249:666-669

Tan, C-K., Castillo, C., So, A. G. and Downey, K. M. (1986) An auxiliary protein for DNA polymerase- $\delta$ from fetal calf thymus. J. Biol. Chem. 261: 12310)12316 
Thompson, N. E., Steinberg, T. H., Aronson, D. B. and Burgess, R. R. (1989) Inhibition of in vivo and in vitro transcription by monoclonal antibodies prepared against wheat germ RNA polymerase II that rea.ct with the heptapeptide repeat of eukaryotic RNA polymerase II. J. Biol. Chem. 264:11511-11520

Towbin, H., Staehelin, T., and Gordon, J. (1979). Electrophoretic transfer of proteins from polyacrylamide gels to nitrocellulose sheets: procedure and some applications. Proc. Natl. Acad. Sci. USA 76:4350-4354

Tuazon, P. T., Merrick, W. C. and Traugh, J. A. (1989) Comparative analysis of phosphorylation of translation initiation and elongation factors by seven protein kinases. J. Biol. Chem. 264:2773-2777

Tuazon, P. T., Morley, S. J., Dever, T. E., Merrick, W. C. Rhoads, R. E. and Traugh, J. A. (1990) Association of initiation factor elF-4E in a cap binding protein complex (eIF-4F) is critical for and enhances phosphoryl...ion by protein kinase C. J. Biol. Chem. 265:10617-10621

Viel, A., Djé, M. K. Mazabraud, A., Denis, H. and Le Maire, M. (1987) Thesaurin a, the major protein of Xenopus laevis previtellogenic oocytes, present in the $42 S$ particles, is homologous to elongation factor EF-1 $\alpha$. 223:232-236

Vogt, P. K., Bos, T. J. and Doolittle R. F. (1987) Homology between the DNAbinding domain of the GCN4 regulatory protein of yeast and the carboxylterminal region of a protein coded for by the oncogene jun. Proc. Natl. Acad. Sci. USA 84:3316-3319

Wang, E. (1985a) A 57,000-mol-wt protein uniquely present in nonproliferating cells and senescent human fibroblasts. J. Cell. Biol. 100:545-551

Wang, E. (1985b) Rapid disappearance of statin, a nonproliferating and senescert cell-specific protein, upon reentering the process of cell cycling. J. Cell. Biol. $101: 1695-1701$

Wang, E. and Krueger, J. G. (1985) Application of an unique monoclonal antibody as a marker for nonproliferating subpopulations of cells of some tissues. J. Histochem. Cytochem. 33:587-594

Wang. E. and Lin, S. L. (1986) Disappearance of statin, a protein marker for nomproliferating and senescent cells, following serum-stimulated cell cycle entry. Exp. Cell Res. 167:135-143 
Wang, E. (1989) Statin, A nonproliferation-specific protein, is associated with the nuclear envelope, and is heterogeneously distributed in cells leaving quiescent state. J. Cell Physiol. 140:418-426

Wang, E., Moutsatsos, I. K. and Nakamura, T. (1989). Cloning and molecular characterization of a cDNA clone to statin, a protein specifically expressed in nonproliferating quiescent and senescent fibroblasts. Exp. Geronto. 24:485-499

Whiteheart, S. W., Shenbagamurthi, P., Chen, L., Cotter, R. J. and Hart, G. W. (1989) Murine elorgation factor $1 \alpha(E F-1 \alpha)$ is posttranslationally modified by novel amide-linked ethanolamine-phosphoglycerol moieties. J. Biol. Chem. 264:14334-14341

Yanishevsky, R. M. and Stein, G. H. (1980) Ongoing DNA synthesis continues in young human diploid cells (HDC) fused to senescent HDC, but entry into $S$ phase is inhibited. Exp. Cell Res. 126:469-472

Weissman, A. (1882) Über die Dauer des Lebens, Jena Germany. 